\title{
A new genus of Theraphosid spider from Mexico, with a particular palpal bulb structure (Araneae, Theraphosidae, Theraphosinae)
}

\author{
Jorge I. MENDOZA ${ }^{1, *}$, Arturo LOCHT ${ }^{2}$, Radan KADERKA ${ }^{3}$, \\ Francisco MEDINA ${ }^{4} \&$ Fernando PÉREZ-MILES ${ }^{5}$ \\ ${ }^{1}$ Colección Nacional de Arácnidos, Departamento de Zoología, Instituto de Biología, \\ Universidad Nacional Autónoma de México, Ciudad Universitaria, 3er circuito exterior, \\ Apto. Postal 70-153, CP 04510, Coyoacán, Distrito Federal, México. \\ ${ }^{2,4}$ Laboratorio de Acarología, Departamento de Biología Comparada, Facultad de Ciencias, \\ Universidad Nacional Autónoma de México, \\ Av. Universidad 3000, Colonia Copilco, 04510 México, D.F., México. \\ ${ }^{3}$ Roztoky u Prahy, Czech Republic. \\ ${ }^{5}$ Sección Entomología, Facultad de Ciencias, Iguá 4225, 11400 Montevideo, Uruguay. \\ *Corresponding autor: nomeireth@hotmail.com \\ ${ }^{2}$ Email: guguslocht 1@yahoo.com \\ ${ }^{3}$ Email: Radan.Kaderka@seznam.cz \\ ${ }^{4}$ Email: pakoleno@yahoo.com \\ ${ }^{5}$ Email: myga@,fcien.edu.uy

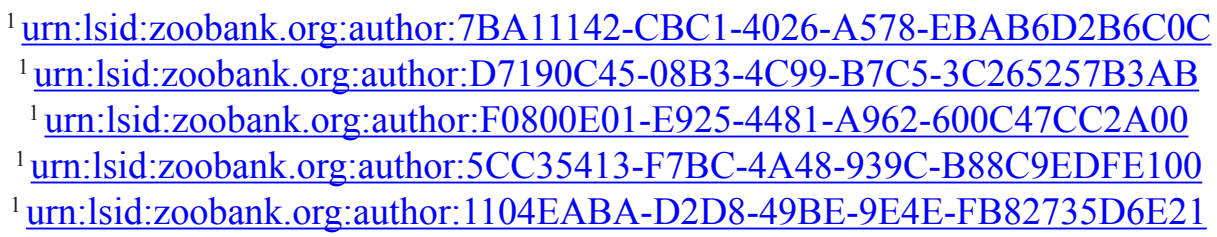

\begin{abstract}
Magnacarina gen. nov. from Mexico is described. Hapalopus aldanus West, 2000 from Nayarit, is transferred to the new genus with an emended diagnosis creating the new combination Magnacarina aldana comb. nov. Three new species are described: Magnacarina moderata Locht, Mendoza \& Medina sp. nov. from Nayarit and Sinaloa; Magnacarina primaverensis Mendoza \& Locht sp. nov. and Magnacarina cancer Mendoza \& Locht sp. nov., both from Jalisco. Magnacarina gen. nov. is characterized by an unusual bifid palpal bulb, and has a primary projection located in the central area of the palpal bulb and directed retrolaterally; this projection possesses the prolateral superior and retrolateral keels. Next to the primary projection is a secondary projection, which may be short or long, ending in the prolateral inferior and apical keel surrounding the sperm pore. This secondary projection may have prolateral accessory keels and is diagnosed by possessing a nodule of inwardly curled megaspines, located in the basal ventro-retrolateral region of metatarsi I in adult males. Additionally, male tibiae I possess three apophyses. Females of Magnacarina gen. nov. have a single reduced and strongly sclerotized spermatheca, with an apical lobe projecting ventrally, and with a uterus externus that is longer and wider than the spermatheca.
\end{abstract}


Key words. Tarantula, taxonomy, bulb morphology, tibial apophyses, new species.

Mendoza J.I., Locht A., Kaderka R., Medina F. \& Pérez-Miles F. 2016. A new genus of Theraphosid spider from Mexico, with a particular palpal bulb structure (Araneae, Theraphosidae, Theraphosinae). European Journal of Taxonomy 232: 1-28. http://dx.doi.org/10.5852/ejt.2016.232

\section{Introduction}

Mexico has the second highest number of formally described tarantula species worldwide, with 84 species (World Spider Catalog 2016). Despite this, Mexican theraphosid spiders have been poorly studied and it is common to find undescribed species and novel genera (Vol 1999, 2000, 2001; Locht et al. 2005; Locht, 2008; Locht \& Medina 2008; Mendoza 2012a, 2012b, 2014a, 2014b; Schmidt 2012; Estrada-Alvarez 2014; Ortiz \& Francke 2014).

West (2000) described Hapalopus aldanus, a small theraphosid from Nayarit state in Mexico, which did not resemble any known theraphosid species. Due to the general shape of the male palpal bulb and female spermatheca, he placed that new species in the genus Hapalopus Ausserer, 1875. Unfortunately, he did not mention which characters linked the new species with Hapalopus. Locht (2008) investigated Hapalopus aldanus West, 2000 and determined the species did not belong to Hapalopus or any other known theraphosid genus. However, it was determined that this species belonged in the Theraphosinae due to the presence of urticating setae of the type III, the oval unipartite spermatheca, and the multiple keels on the male palpal bulb, which are the diagnostic features of this subfamily. Locht also indicated it might represent an undescribed genus because of the very distinctive shape of male palpal bulb.

After examining spider collections in the American Museum of Natural History (AMNH), the Colección Nacional de Arácnidos (CNAN) and the Laboratorio de Acarología Anita Hoffman (LAAH), we noticed more specimens with the same male palpal bulb morphology as in H. aldanus. Following confirmation that these specimens possessed the three tibial apophyses and cluster of megaspines in the basoretrolateral area of metatarsi I, as indicated by Locht (2008), it was determined that these specimens belonged to a new genus of subfamily Theraphosinae. Herein, we describe Magnacarina gen. nov. and three additional new species, transferring $H$. aldanus to represent the type species. Additionally, we propose new nomenclature for the unique features in the male palpal bulb morphology.

\section{Material and methods}

All measurements are in millimeters; smaller structures were measured using an ocular micrometer on a stereo microscope Nikon SMZ645, larger structures with a digital caliper General UltraTech (error of $0.1 \mathrm{~mm}$ ). Leg and palp measurements were taken along the dorsal central axis of the left side. Description of tarsal scopulae follows Pérez-Miles (1994). Male palpal bulb keel terminology follows Bertani (2000). For comparative purposes, it is necessary to properly position the bulb, with the subtegulum pointing upwards as when extended for mating (Goloboff 1995; Bertani 2000). The primary projection is a structure located in the central area of the palpal bulb and is directed retrolaterally; this projection is apparently formed by the extension of prolateral superior and retrolateral keels (Figs 2, $6,9,14)$. Next to this projection is the secondary projection that ends with the prolateral inferior and apical keels surrounding the sperm pore (Figs 2E, 6E, 9E, 14E). The secondary projection may also have prolateral accessory keels, better observed in prolateral or frontal view (Figs 9D, 14D). Position of the keels were compared with other related theraphosids: Bonnetina Vol, 2000; Cardiopelma Vol, 1999; Cyriocosmus Simon, 1903; Davus O. Pickard-Cambridge, 1892; Hapalopus Ausserer, 1875 and Schizopelma F.O. Pickard-Cambridge, 1897. 
Spination description follows Mendoza (2014a). Terminology of tibial apophyses follows the general usage for Theraphosidae (Bertani 2001). The term "accessory apophysis", recently proposed by Ortiz \& Francke (2014) for Bonnetina, is also used. In species historical references, we follow the World Spider Catalog (2016): D = Described. Photographs (Figs 1-3, 5-11, 13-15) were taken with a Nikon Coolpix S10 VR digital camera coupled to a stereomicroscope. The following photographs were provided as follows: Fig. 4 by Rick C. West; Fig. 12C-D by G. Vila. Photographs of Fig. 12A-B were taken with a digital camera Canon G12 in laboratory and field respectively.

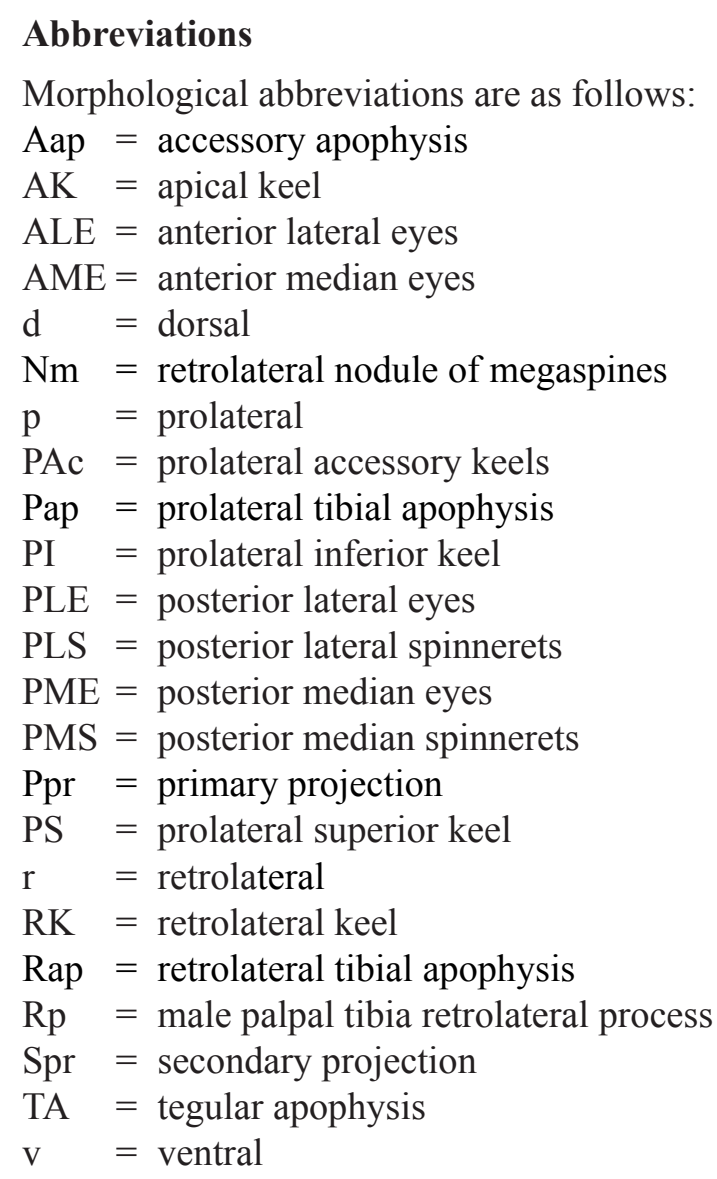

Examined specimens are deposited in the following institutions:

$\mathrm{AMNH}=$ American Museum of Natural History, New York

CNAN $=$ Colección Nacional de Arácnidos, México City

LAAH $=$ Laboratorio de Acarología Anita Hoffman; México City

NHM = Natural History Museum, London (formerly BMNH)

UNAM $=$ Universidad Nacional Autónoma de México, Mexico City

\section{Material examined for comparisons}

Bonnetina aviae Estrada-Alvarez \& Locht, 2011

MEXICO: 2 đ̂̉, Veracruz, Perote, Totalco, 15 Jun. 2015, coll. P. Berea (CNAN-Ar003708); 1 , Veracruz, Perote, cerca de San Antonio Limón, 19 Dec. 2010, colls J. Mendoza, E. Hijmensen, E. Goyer and S. Longhorn (CNAN-Ar003534B).

Bonnetina papalutlensis Mendoza, 2012

MEXICO: 1 o, 1 ㅇ, Guerrero, Eduardo Neri, $1 \mathrm{~km} \mathrm{~N}$ of Milpillas, 22 Sep. 2012, colls D. Ortiz, J. Mendoza, J. Cruz and G. Contreras (CNAN-Ar003723A, CNAN-Ar003723D). 
Cardiopelma mascatum Vol, 1999

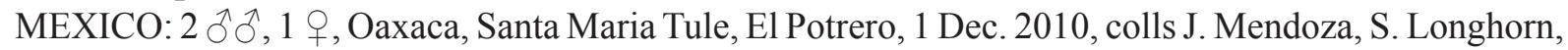
E. Hijmensen and E. Goyer (CNAN 4092).

Cyriocosmus elegans (Simon, 1889)

VENEZUELA: 1 ô donated by J. Mendoza (CNAN-Ar003298).

Davus pentaloris (Simon, 1888)

MEXICO: 1 ðै, Veracruz, Copital, Medellin, El Mangal, 14 Dec. 2010, colls J. Mendoza, S. Longhorn, E. Hijmensen and E. Goyer (CNAN-Ar003634); 1 क, Veracruz, Copital, Medellin, El Mangal, 14 Dec. 2010, coll. G. Monter (CNAN-Ar003523).

Hapalopus formosus Ausserer, 1875

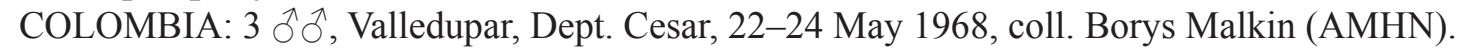

\title{
Schizopelma bicarinatum F.O. Pickard-Cambridge, 1897
}

MEXICO: 1 o (holotype), 1 क (paratype), Guerrero, Xantipa (currently Chautipan) (BMNH 1898.12.24.57.-60); 1 ô, Guerrero, Chilpancingo de los Bravo, Acahuizotla, 19 Nov. 1969, without collector data (CNAN-Ar003511).

\section{Schizopelma sp.}

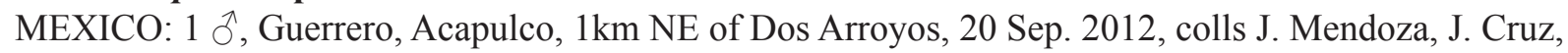
G. Contreras and D. Ortiz (CNAN-Ar010328).

\section{Results}

\author{
Phyllum Arthropoda Latreille, 1829 \\ Class Arachnida Lamarck, 1801 \\ Order Araneae Clerck, 1757 \\ Infraorder Mygalomorphae Pocock, 1892 \\ Family Theraphosidae Thorell, 1869 \\ Subfamily Theraphosinae Thorell, 1870 \\ Magnacarina gen. nov. \\ urn:1sid:zoobank.org:act:B0477B69-2908-44AA-86A6-ACC8C37DCE74
}

Figs 1-16

\section{Type species}

Magnacarina aldana (West, 2000) comb. nov.

\section{Diagnosis}

Magnacarina gen. nov. differs from all other known theraphosine genera, except Bonnetina, in having three apophyses on male tibia I and a retrolateral nodule on metatarsus I. Males differ from Bonnetina in having a bifid palpal bulb that possesses a primary and secondary projections. Additionally, Magnacarina gen. nov. differs in possessing a retrolateral nodule of metatarsus I with megaspines, whereas Bonnetina has a granular one. Females differ in possessing a very low semicircular spermatheca with a uterus externus that is longer and wider than the Bonnetina triangular, domiform or digitiform spermatheca. Magnacarina gen. nov. has the following character combination: bifid shape of male palpal bulb with one sperm pore. It has a primary projection, located in the central area of palpal bulb and directed retrolaterally. This projection possesses the prolateral superior and retrolateral keels. The prolateral superior keel is large, extending posteriorly to palpal bulb back face. Posterior extension of the prolateral superior keel 
may extend to the palpal bulb back face (as in M. aldana comb. nov.), close to border of back face (as in M. primaverensis Mendoza \& Locht sp. nov.), or extend only until the middle portion of the palpal bulb prolateral face (as in M. cancer Mendoza \& Locht sp. nov. and M. moderata Locht, Mendoza \& Medina sp. nov.). Following the primary projection is a secondary projection (long or short), ending with the prolateral inferior and apical keels surrounding the sperm pore. The prolateral inferior keel is
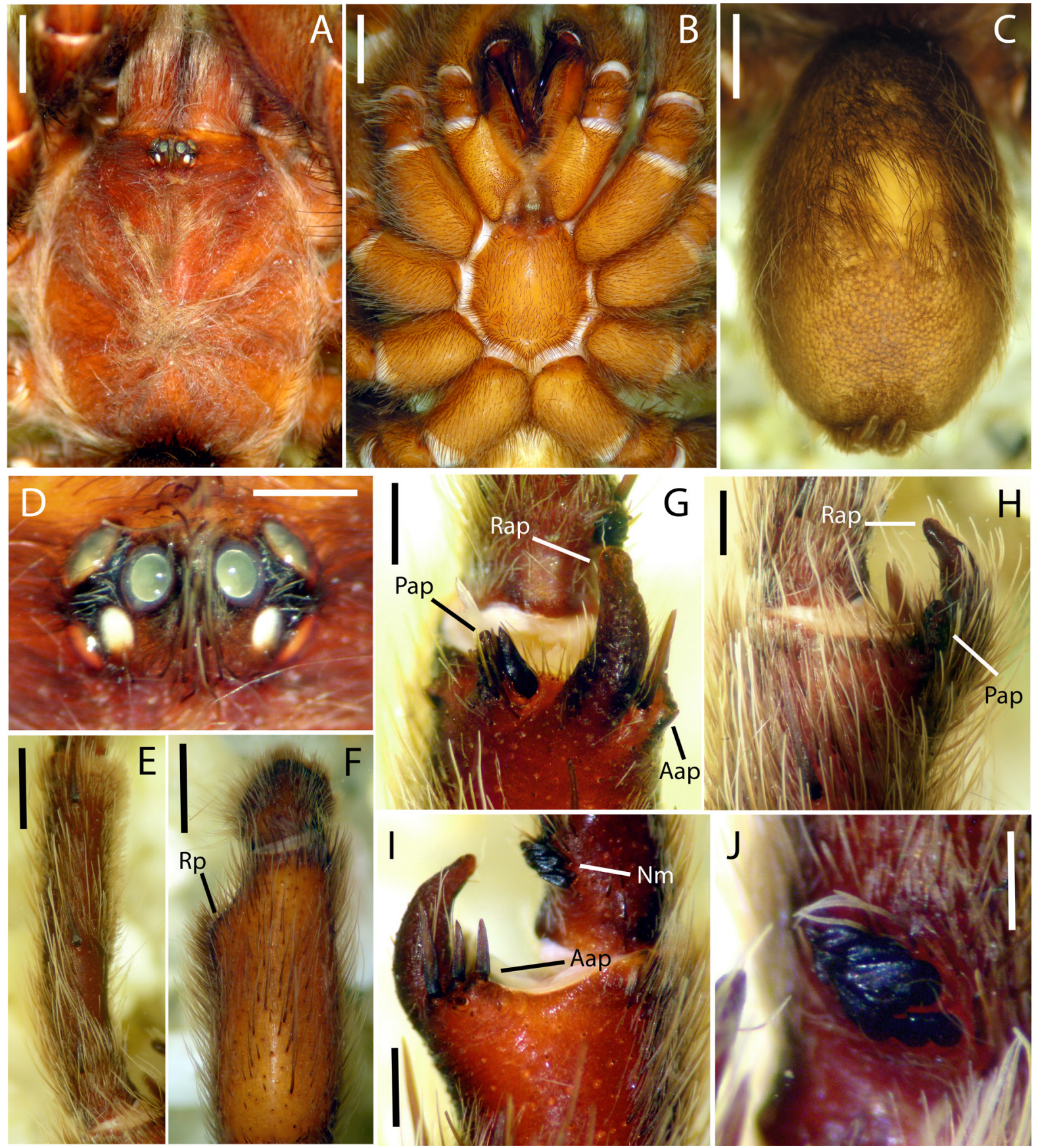

Fig. 1. Magnacarina aldana (West, 2000), §̂, paratype (LAAH). A. Carapace, dorsal view. B. Prosoma, ventral view. C. Opisthosoma, dorsal view. D. Ocular tubercle, dorsal view. E-J. Left side. E. Metatarsus I, Prolateral view. F. Palp tibia, dorsal view. G. Tibial apophyses, ventral view. H. Tibial apophyses, prolateral view. I. Tibial apophyses, retrolateral view. J. Retrolateral nodule with megaspines, retrolateral view. Scale bars: A-C $=2 \mathrm{~mm} ; \mathrm{E}, \mathrm{F}=1 \mathrm{~mm} ; \mathrm{D}, \mathrm{G}-\mathrm{I}=0.5 \mathrm{~mm}$. 
always the widest distally. The secondary projection may have prolateral accessory keels that are variable in size and number. Males have a nodule of prolaterally curled megaspines, located at the basal ventroretrolateral region of metatarsi I (except for M. moderata sp. nov.). Male tibiae I with three apophyses. The accessory apophysis well to slightly developed, with apical spines variable in size and number. Urticating setae of the type III arranged in one dorsomedian patch. Females with very low spermatheca and single semicircular receptacle. Uterus externus always longer and wider than spermatheca.

\section{Remarks}

Adult males of Magnacarina gen. nov. have a retrolateral nodule of megaspines, located in the retrolaterobasal region of metatarsus I (except M. moderata sp. nov.). This nodule is considered homologous to the granular one found in Bonnetina, so it is possible that these genera are closely related.
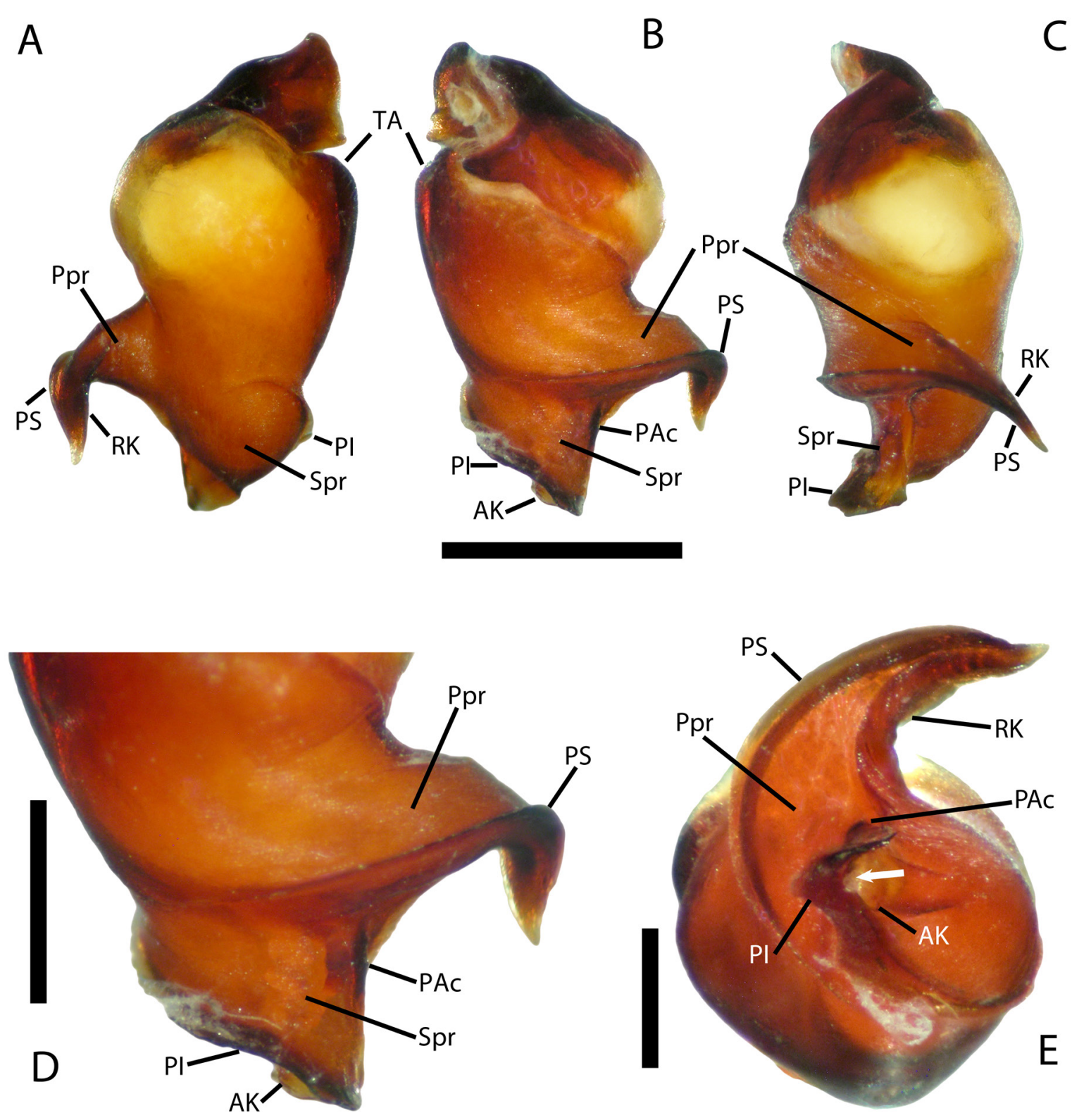

Fig. 2. Magnacarina aldana (West, 2000), ふ̋, paratype (LAAH). Left palpal bulb. A. Retrolateral view. B. Prolateral view. C. Dorsal view. D. Apex, prolateral view. E. Apex, apical view. White arrow indicates sperm pore. Scale bars: $\mathrm{A}-\mathrm{C}=1 \mathrm{~mm} ; \mathrm{D}, \mathrm{E}=0.5 \mathrm{~mm}$. 


\section{Etymology}

The genus gender is feminine, comprising magnus, a Latin adjective meaning "very large" or "great", and the Latin word carina, which means "keel". Generic name refers to the very large primary projection in the male palpal bulb (Figs 2D, 6D, 9D, 14D).

\section{Distribution}

Magnacarina gen. nov. is endemic to Mexico and only known from the states of Sinaloa, Nayarit and Jalisco. The genus inhabits the deciduous forest along the Pacific coast to the foothills of the Sierra
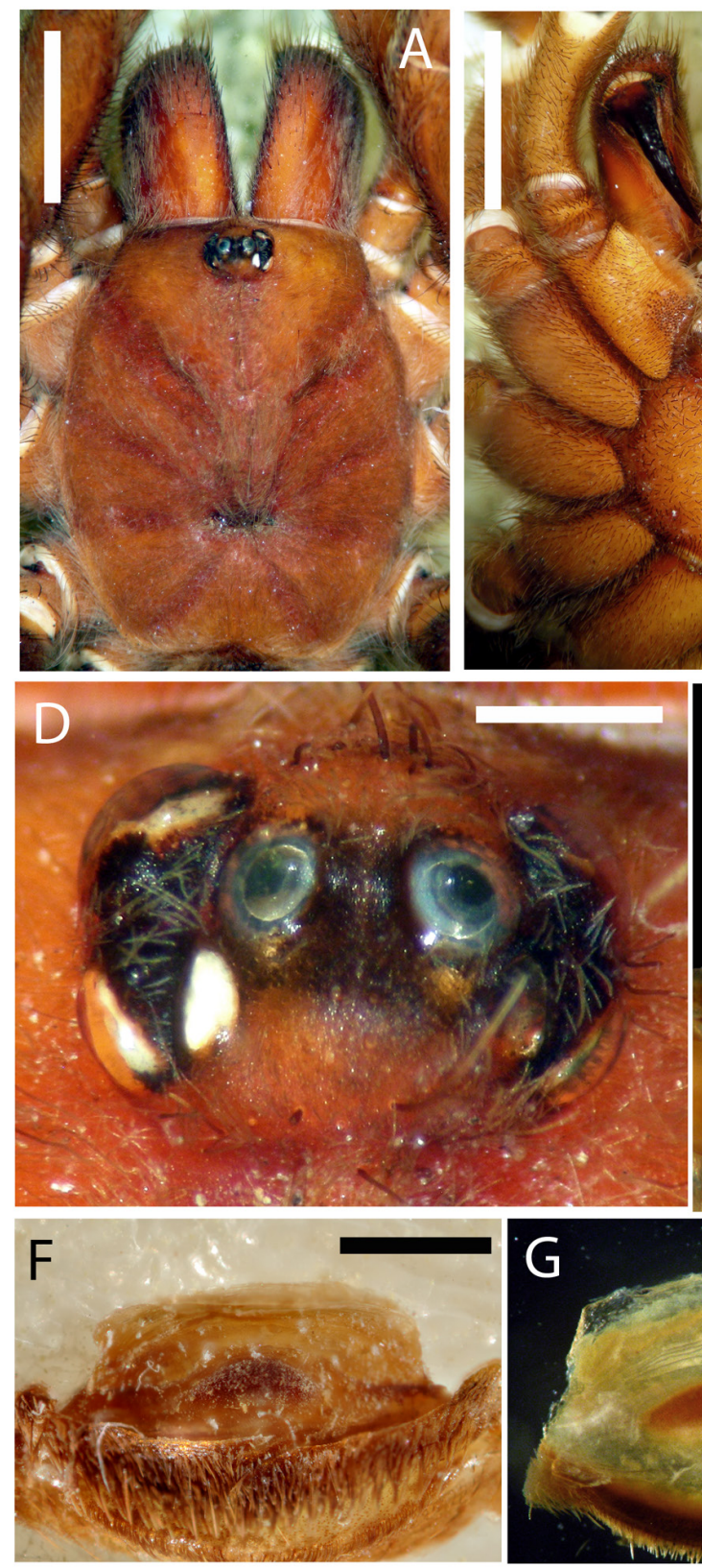
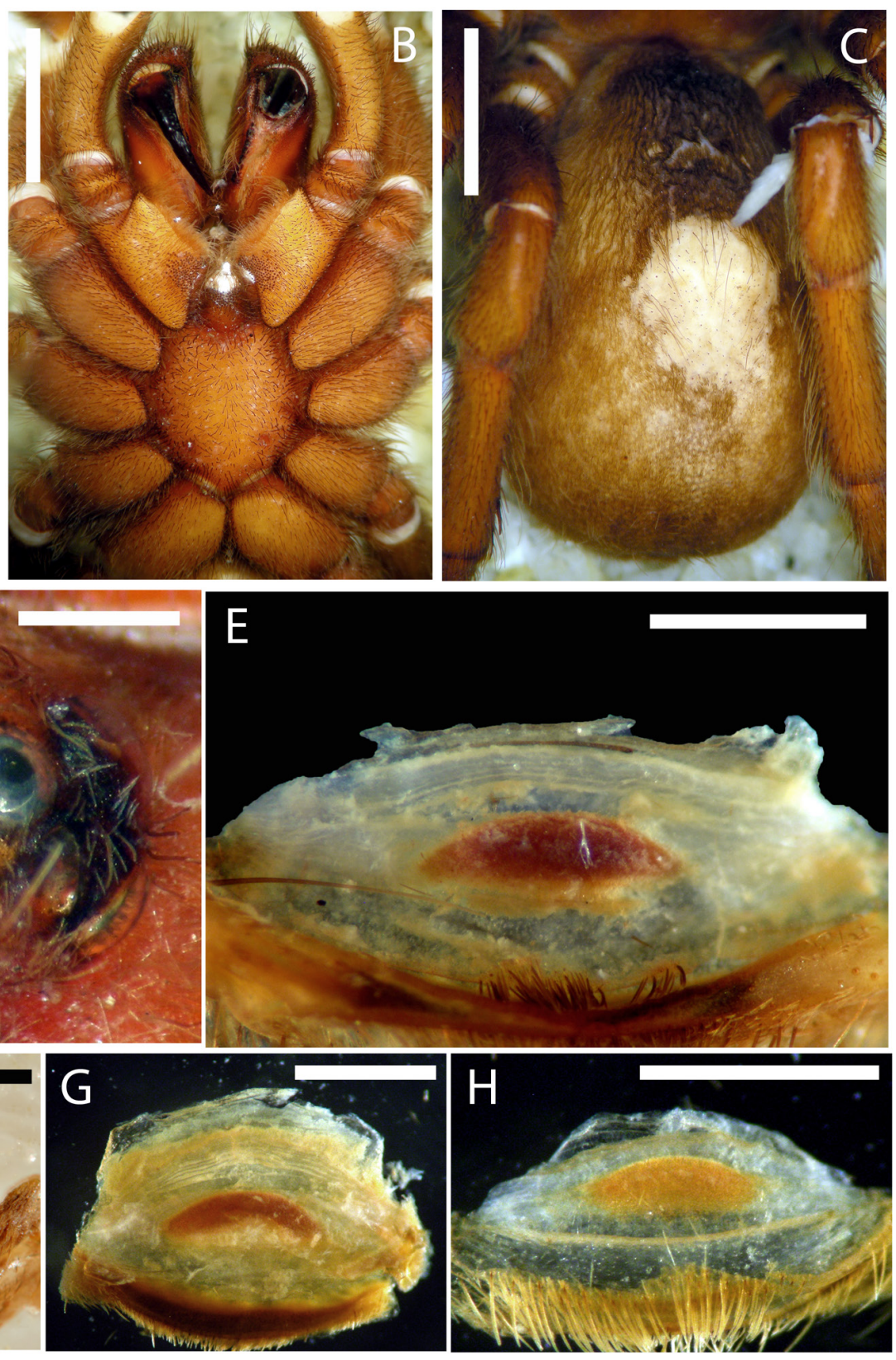

Fig. 3. Magnacarina aldana (West, 2000). A-E. + , paratype (LAAH). A. Carapace, dorsal view. B. Prosoma, ventral view. C. Opisthosoma, dorsal view. D. Ocular tubercle, dorsal view. E. Spermatheca, ventral view. F-H. Spermatheca ventral view. F. + , paratype $(\mathrm{AMNH})$. G. $q$, paratype (LAAH). H. $q$ (CNAN-Ar010276). Scale bars: A-C $=4 \mathrm{~mm} ; \mathrm{E}-\mathrm{H}=1 \mathrm{~mm} ; \mathrm{D}=0.5 \mathrm{~mm}$. 
Madre Occidental. Specimens collected during fieldwork were found under rocks, in shallow burrows or superficial scrapes covered with silk.

Magnacarina aldana (West, 2000) comb. nov.

Figs 1-4

Hapalopus aldanus West, 2000: 299, fig. 1 A-D (D ぷ+ ).

Hapalopus aldanus - Schmidt 2003: 168, figs 386-389 (ð̊ํ) .

\section{Emended diagnosis}

Magnacarina aldana comb. nov. males differ from M. cancer sp. nov. in possessing a thinner prolateral inferior keel that is distally rounded and oriented to the apex, and the retrolateral apophysis is thinner apically; females differ in possessing a wider spermatheca. Magnacarina aldana comb. nov. differs from $M$. primaverensis sp. nov. in possessing a highly developed accessory apophysis and a lower number of prolateral accessory keels as well as in the thinner prolateral inferior keel and the coloration of the carapace and legs in both sexes. Magnacarina aldana comb. nov. differs from M. moderata sp. nov. in that males have a retrolateral nodule of megaspines and females a medially longer spermatheca.

Magnacarina aldana comb. nov. is characterized by the following character combination: male palpal bulb with a prominent primary projection that is strongly curved retrolaterally (Fig. 2A); retrolateral and prolateral superior keels thin and well developed, posterior extension of prolateral superior keel ends

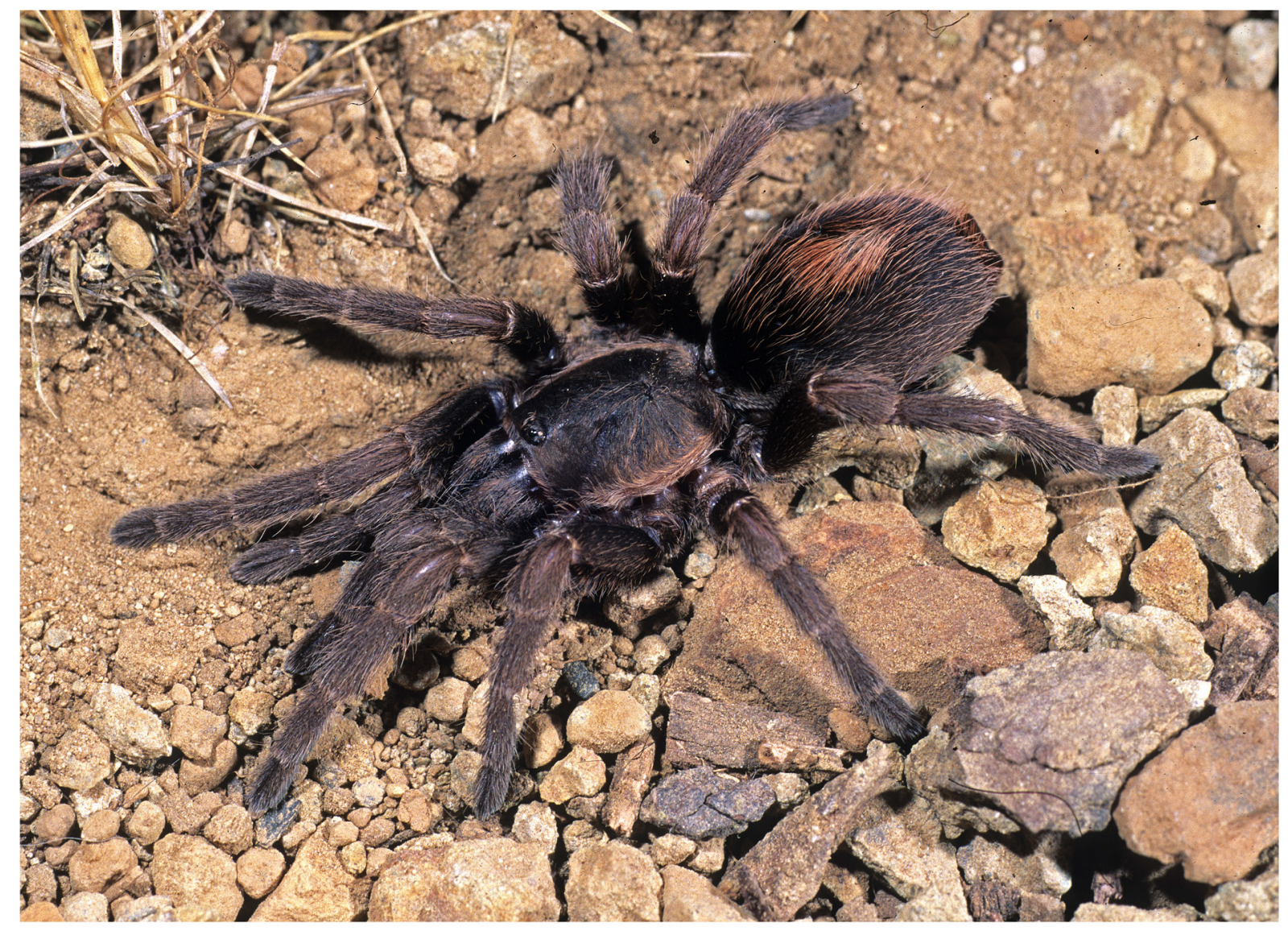

Fig. 4. Magnacarina aldana (West, 2000), habitus; + , in habitat (Nayarit) Photo: R.C. West. 
Table 1. Magnacarina aldana (West, 2000) and Magnacarina cancer Mendoza \& Locht sp. nov. Variations of some quantitative characters in the specimens of the type series. Measurements in $\mathrm{mm}$. Hyphens represent the interval between the lowest and highest value of each character. When left and right side values were taken, it was indicated as (left/right).

\begin{tabular}{l|cc|cc}
\hline \multicolumn{1}{c|}{ Specimens measurements } & \multicolumn{2}{c|}{ Magnacarina aldana sp. nov. } & \multicolumn{2}{c}{ Magnacarina cancer sp. nov. } \\
\hline \multirow{2}{*}{ Total length } & Males (2) & Females (4) & Males (3) & Females (1) \\
\cline { 2 - 5 } Carapace length & $20.26,20.31$ & $16.81-31.00$ & $10.15-16.47$ & 13.7 \\
Carapace width & $7.92,8.17$ & $6.32-10.33$ & $5.33-7.45$ & 5.2 \\
Sternum length & $6.33,7.42$ & $5.70-9.17$ & $4.0-7.18$ & 4.5 \\
Sternum width & $3.20,3.50$ & $2.73-4.38$ & $2.80-3.17$ & 2.45 \\
Labium length & $3.00,3.25$ & $2.73-3.81$ & $2.78-3.16$ & 2.4 \\
Labium width & $0.90,0.94$ & $0.87-1.25$ & $0.83-1.0$ & 1.0 \\
Cheliceral teeth (left/right) & $1.20,1.25$ & $1.20-1.50$ & $1.20-1.30$ & 1.11 \\
Labial cuspules & $9 / 10$ & $9 / 10$ & $11 / 10-12$ & $8 / 8$ \\
Maxillary cuspules (left/right) & 52,84 & $52-73$ & $26-29$ & 60 \\
Spermatheca length medially & $145-157 / 132-159$ & $112-179 / 91-201$ & $66-109 / 68-110$ & $97 / 100$ \\
Spermatheca base width & - & $0.23-0.41$ & - & 0.17 \\
Accesorial apophysis spines (left side) & - & $0.77-1.06$ & - & 0.8 \\
Number of megaspines in nodule (left side) & 10 & - & $3-5$ & - \\
\hline
\end{tabular}

on the back face (Fig. 2D-E); secondary projection possesses two prolateral accessory keels (Fig. 2B, D). Prolateral inferior keel wide and increasing from posterior to apical (Fig. 2C-E). Apical keel well developed, covering the sperm pore that opens towards prolateral (Fig. 2D-E). Prolateral apophysis conical with one inner spine longer than its length (Fig. 1G-H); retrolateral apophysis strongly curved to dorsal (Fig. 1H-I); accessory apophysis slightly developed (Fig. 1G, I). Male palpal tibia retrolateral process short subconical, slightly developed on distal third (Fig. 1F). Spermatheca reduced and low, with one single semicircular, strongly sclerotized receptacle. Uterus externus is three times wider, and longer than the spermatheca (Fig. 3E-H). Variations summarized in Table 1.

\section{Type material examined}

\section{Holotype}

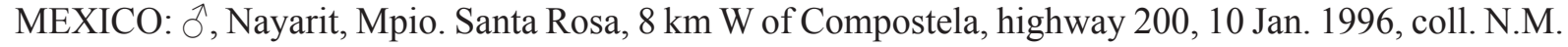
Palomera (AMNH).

\section{Allotype}

MEXICO: + , same data as the holotype (AMNH).

\section{Paratypes}

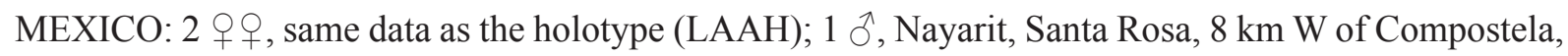
highway 200, 11 Jan. 1996, coll. N.M. Palomera (LAAH).

\section{Other material examined}

MEXICO: 1 + , Nayarit, 8 km S. of Compostela, Jul. 1996, coll. N. Palomera and R.C. West (CNANAr010267). 


\section{Distribution and natural history}

Only known from the type locality. West (2000) mentioned that all specimens were collected in tropical deciduous forest while clearing land near cattle pastures. Males were found wandering during the daytime and females were found in shaded areas residing in scrapes under large rocks or fallen logs. He also indicated that the species is sympatric with Aphonopelma nayaritum (Chamberlin, 1940).

\section{Magnacarina cancer Mendoza \& Locht sp. nov. urn:Isid:zoobank.org:act:8B262491-E2F2-43F2-BA8A-A81EBE09D842}

Figs $5-7,16$

\section{Diagnosis}

Magnacarina cancer sp. nov. differs from all other Magnacarina species in the general shape of the male palpal bulb, with a prolateral inferior keel pointing to primary projection - resembling a crab claw. Secondary projection lacking prolateral accessory keels. Also M. cancer sp. nov. differs from other species in possessing a more developed accessory apophysis. Females differ in having a very reduced spermatheca.

Magnacarina cancer sp. nov. possesses the following character combination: male palpal bulb with a short primary projection, with distal half twisted to apical (Fig. 6A-C); retrolateral keel slightly developed; prolateral superior keel wide and well developed, posterior extension ends at the middle of prolateral face (Fig. 6D-E). Secondary projection short, lacking prolateral accessory keels (Fig. 6D). Prolateral inferior keel short and broader distally, apex acute and directed to Ppr - resembling a crab claw (Fig. 6A-B, E). Apical keel wide and covering the sperm pore (Fig. 6E). Accessory apophysis pointed dome shape and well developed (Fig. 5H). The retrolateral apophysis is thicker on distal half. The retrolateral nodule of megaspines very short and wide (Fig. 5F, I-J). Spermatheca very reduced, only a small rounded receptacle, as long as wide. Uterus externus is five times wider, and three times longer than the spermatheca (Fig. 7D).

\section{Etymology}

The specific epithet is in reference to the Latin word cancer (crab), describing the shape and orientation of the primary projection and apical keel that resembles a crab claw.

\section{Type material}

\section{Holotype}

MEXICO: đ̊ Jalisco, Tomatlán, Estación de Biología Chamela, 7 Mar. 1990, coll. S. Guzmán(CNAN-T0991).

\section{Paratypes}

MEXICO: 1 \&, Jalisco, Tomatlán, Estación de Biología Chamela, 10 Jan. 1990, coll. S. Guzmán (CNAN-T0992); 1 đ̃, same locality, 6 Feb. 1990, coll. S. Guzmán (CNAN-T0993); 1 ô, same locality, 19 Feb. 1990, coll. S. Guzmán (CNAN-T0994); 1 ô, same locality, 4 Mar. 1987, coll. S.H. Bullock (LAAH).

\section{Description}

Holotype male CNAN-T0991 (Figs 5-6)

Body length (not including chelicerae and spinnerets) 10.15, carapace: 5.33 long, 4.0 wide. Caput not markedly elevated; fovea procurved, 0.95 wide. Carapace without dark cephalic area (Fig. 5A). Eyes: anterior eye row procurved, posterior eye row recurved. Eyes sizes and interocular distances: AME 0.26; ALE 0.36; PME 0.16; PLE 0.32; AME-AME 0.10; AME-ALE 0.04; PME-PME 0.42; PME-PLE 0.03; ALE-PLE 0.04. Ocular tubercle, width 1.16; length 0.88; clypeus lacking (Fig. 5D). Labium: length 
0.90; width 1.20; with 26 cuspules. Maxilla inner corner with approximately 66-68 (left-right). Cheliceral promargin with 11-11 teeth (left-right). Sternum length 2.80. Sigilla oval, first to third hardly visible; posterior sigilla one and half times its length from the margin (Fig. 5B). Leg formula: IV > I > II > III. Length of legs and palpal segments (femur, patella, tibia, metatarsus, tarsus, total): I: 5.72, 3.54, 4.49,
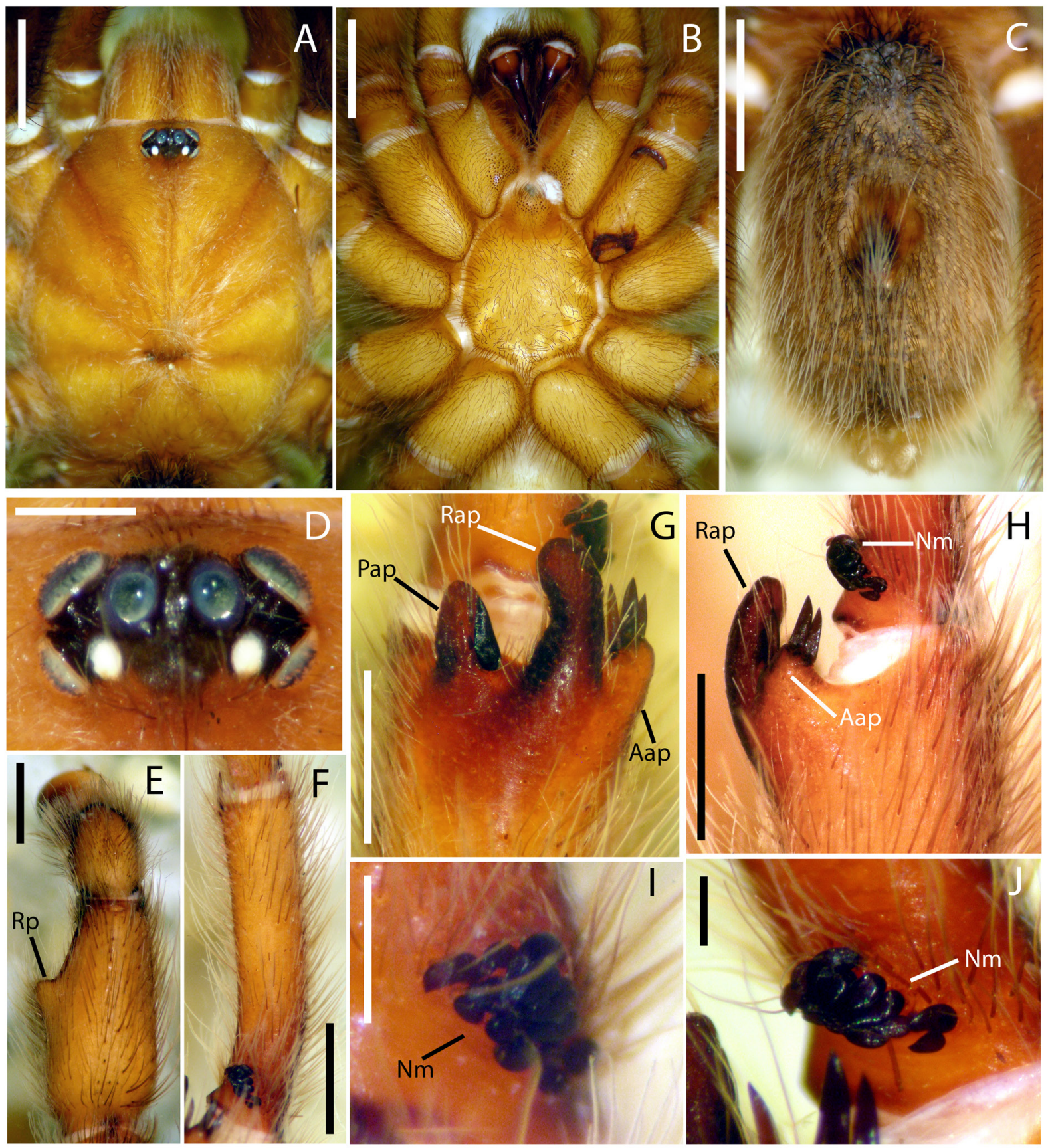

Fig. 5. Magnacarina cancer Mendoza \& Locht sp. nov., đ̂, holotype (CNAN-T0991). A. Carapace, dorsal view. B. Prosoma, ventral view. C. Opisthosoma, dorsal view. D. Ocular tubercle, dorsal view. E-J. Left side. E. Palp tibia, dorsal view. F. Metatarsus I, retrolateral view. G. Tibial apophyses, ventral view. H. Tibial apophyses, retrolateral view. I. Retrolateral nodule with megaspines, ventral view. J. Retrolateral nodule with megaspines, retrolateral view. Scale bars: A-C $=2 \mathrm{~mm}$; $-\mathrm{H}=1 \mathrm{~mm}$; D, $\mathrm{I}-\mathrm{J}=0.5 \mathrm{~mm}$. 
3.53, 3.05, 20.33; II: 4.76, 2.96, 3.61, 3.64, 2.96, 17.93; III: 4.32, 2.26, 3.49, 4.18, 2.90, 17.15; IV: 6.11, 2.42, 4.93, 5.59, 3.39, 22.44. Palp: 3.61, 2.25, 3.27, -, 1.62, 10.75. Spinnerets: PMS, 0.77 long, 0.30 apart; PLS, 1.10 basal, 0.70 middle, 1.06 distal. Tarsi I-IV scopulate, I to III divided by narrow band of setae, IV divided by strong band of setae. Metatarsi I scopulate on distal third; II scopulate on distal third, III slightly scopulate on distal third, and IV slightly scopulate on distal fourth. Tibia I with three apophyses. Prolateral apophysis conical with smaller internal spine. Retrolateral apophysis wide through its length, thick and slightly curved to dorsal position at apex (Fig. 5G-H). Accesory apophyses pointed dome shape and well developed, bearing three megaspines at the apex (Fig. 5H). Metatarsus I curved (Fig. 5F),
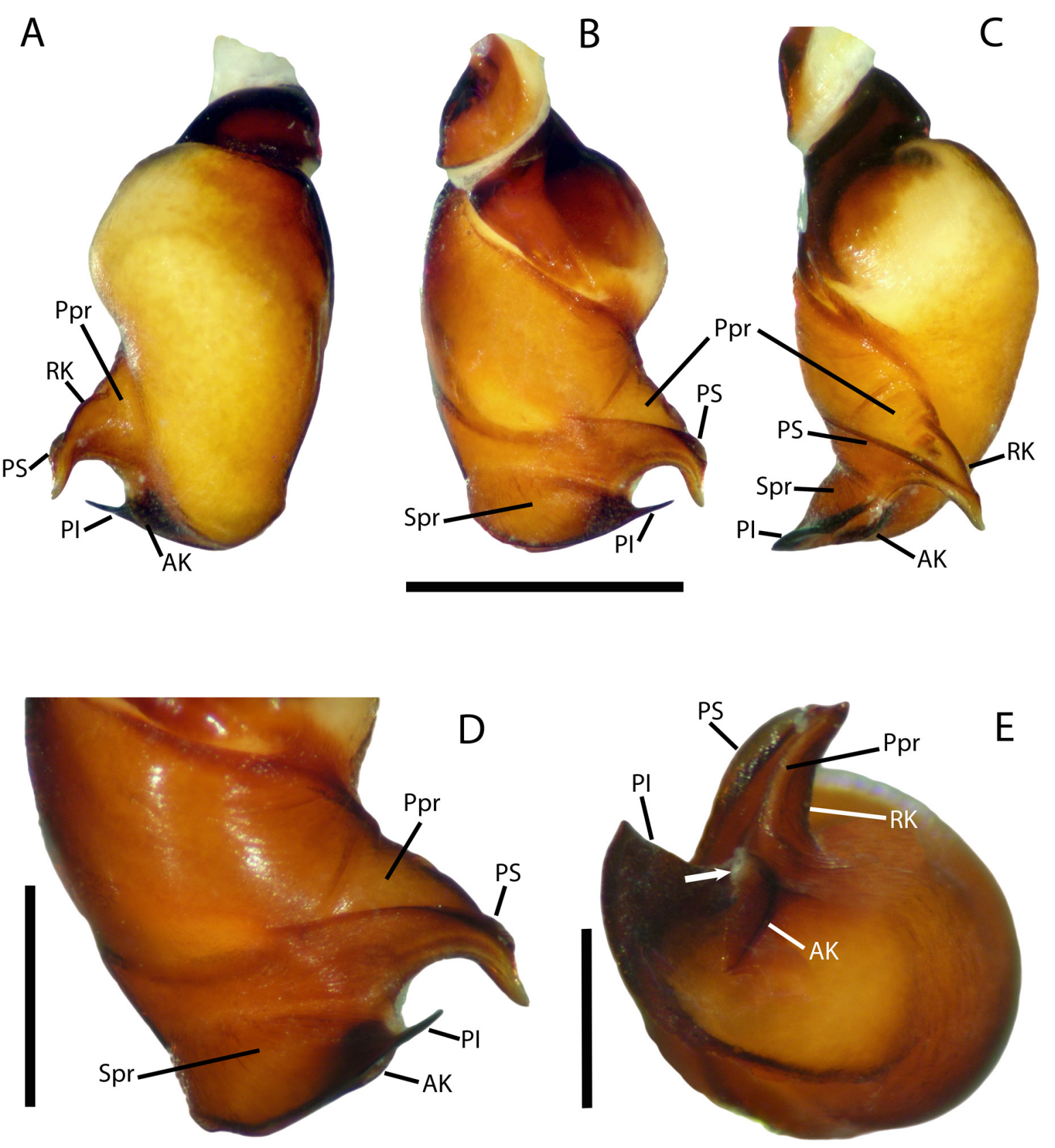

Fig. 6. Magnacarina cancer Mendoza \& Locht sp. nov., ổ, holotype (CNAN-T0991), left palpal bulb. A. Retrolateral view. B. Prolateral view. C. Dorsal view. D. Apex, prolateral view. E. Apex, apical view. White arrow indicates sperm pore. Scale bars: A-C $=1 \mathrm{~mm}$; $-\mathrm{E}=0.5 \mathrm{~mm}$. 
with retrolateral megaspines nodule well developed, having 12 very short and wide spines (Fig. 5I-J). Retrolateral face of palpal tibiae with a prominent conical process in the middle, covered by short setae (Fig. 5E). Chaetotaxy (left side): femora I 1p; II 1p; III 1r; IV 1r; palp 1p; patellae none; tibiae I 2p, 4v; II 2p, 6v; III 2p, 5v, 2r; IV 5v, 2r; palp none; metatarsi: I 1v; II 2p, 6v; III 4p, 6v, 2r; IV 2p, 7v, 2r. Palpal bulb with short and wide primary projection, strongly curved retrolaterally and its distal half twisted to apical. Retrolateral keel thin and slightly developed. Prolateral superior keel wide and well developed, posterior extension ends in the middle of prolateral face (Fig. 6A-D). Secondary projection short lacking, prolateral accessory keels (Fig. D). Prolateral inferior keel short and broader distally, apex acute and directed to primary projection (Fig. 6D-E), shape similar to the crab claw (Fig. 6A-B). Apical keel wide covering the sperm pore, which opens towards prolateral face (Fig. 6E). Lacking tegular apophysis. Urticating setae type III arranged in one oval dorsomedian patch, with copper metallic iridescence, intermixed with long yellowish setae (Fig. 5C). Variations summarized in Table 1.

Color pattern: damaged by preservation in ethanol, carapace tegument looks yellowish; ventral coxae, labium, maxillae and sternum brown; abdomen dorsally brown with whitish setae, ventrally brown. Legs and palps yellowish.

\section{Paratype female CNAN-T0992 (Fig. 7A-D)}

Body length (not including chelicerae and spinnerets) 13.70, carapace: 5.20 long, 4.50 wide. Caput not markedly elevated; fovea recurved, 0.70 wide. Carapace without dark cephalic area (Fig. 7A). Eyes: anterior eye row procurved, posterior eye row recurved. Eyes sizes and interocular distances: AME: 0.23; ALE: 0.28; PME: 0.12; PLE: 0.22; AME-AME: 0.10; AME-ALE: 0.05; PME-PME: 0.38; PME-PLE: 0.02; ALE-PLE: 0.06. Ocular tubercle, width 0.98; length 3.50; clypeus 0.06 (Fig. 7C). Labium: length 1.10; width 1.11; with 60 cuspules. Maxilla inner corner with approximately 97-100 (left-right). Cheliceral promargin with 8-8 (left-right) teeth. Sternum length 2.45 . Sigilla oval, first to third pairs hardly visible; posterior sigilla once its length from the margin (Fig. 7B). Leg formula: IV > I > II > III. Length of legs and palpal segments (femur, patella, tibia, metatarsus, tarsus, total): I: 3.79, 2.54, 2.92, 2.11, 1.69, 13.05; II: 3.47, 2.32, 2.54, 2.01, 2.05, 12.39; III: 2.92, 1.69, 2.17, 2.12, 1.62, 10.52; IV: 4.10, 2.07, 3.20, 3.36,
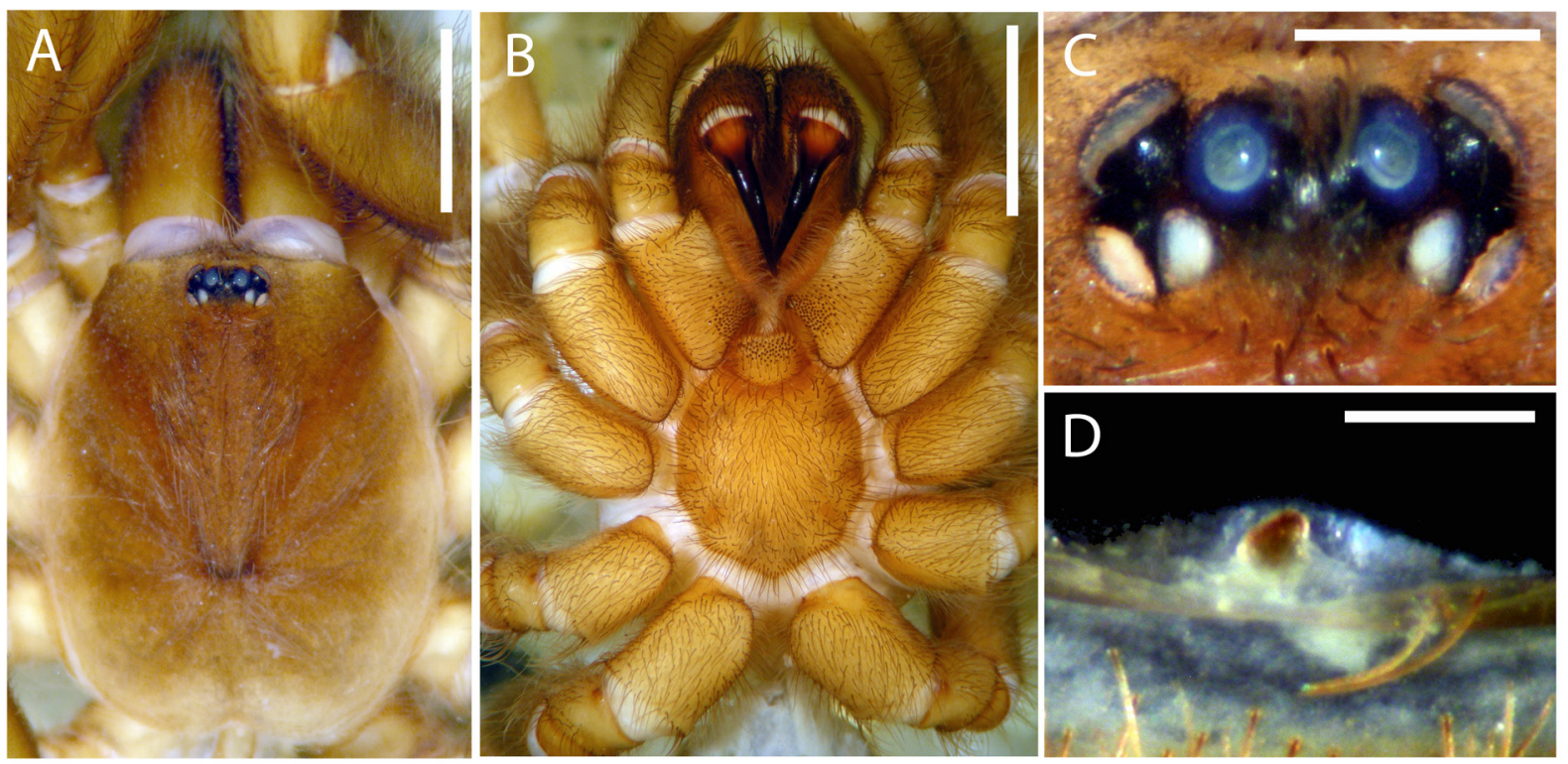

Fig. 7. Magnacarina cancer Mendoza \& Locht sp. nov., + , paratype (CNAN-T0992). A. Carapace dorsal view. B. Prosoma, ventral view. C. Ocular tubercle, dorsal view. D. Spermatheca, ventral view. Scale bars: $\mathrm{A}-\mathrm{B}=2 \mathrm{~mm} ; \mathrm{D}=1 \mathrm{~mm} ; \mathrm{C}=0.5 \mathrm{~mm}$. 
2.23, 14.96. Palp: 3.19, 1.84, 2.09, -, 1.94, 9.06. Spinnerets: PMS, 0.825 long, 0.30 apart; PLS, 1.375 basal, 0.95 middle, 1.15 distal. Tarsi I-IV scopulate, I to III divided by narrow band of setae, IV divided by strong band of setae. Metatarsi I scopulate on distal half; II scopulate on distal half, III scopulate on distal third, and IV scopulate on distal fourth. Chaetotaxy (left side): femora I 1p; II 1p; palp 1p; patellae none; tibiae III 1p, 3v, 1r; IV 2v, 1r; metatarsi I 2v; II 2v; III 4p, 5v, 2r; IV 2p, 7v, 3r. Spermatheca very reduced, only a rounded receptacle as long as wide. Strongly sclerotized with the top oriented ventrally. Uterus externus is five times wider and three times longer than the spermatheca (Fig. 7D). Urticating setae of type III arranged in one dorsomedian patch, with copper metallic iridescence. Variations summarized in Table 1.

Color pattern: damaged by preservation in ethanol, carapace tegument looks yellowish; ventral coxae, labium, maxillae and sternum brown; abdomen dorsally brown with whitish setae, ventrally brown. Legs and palps: yellowish.

\section{Distribution}

The species is known only from the type locality in the Natural Protected Area of Chamela in Jalisco (Fig. 16). Specimens were collected in scrapes under medium size rocks and the males wandering during daytime. Nothing is known about its life cycle or natural history. We know, however, that the same area is inhabited by Brachypelma klaasi (Schmidt \& Krause, 1994), Bonnetina cyaneifemur Vol, 2000, and Aphonopelma sp., so it is possible there exists competition or even predation of M. cancer sp. nov. by these larger species.

Magnacarina primaverensis Mendoza \& Locht sp. nov. urn:1sid:zoobank.org:act:FF12650D-1E0E-43A6-9056-D98A65A794E4

Figs $8-12,16$

\section{Diagnosis}

Magnacarina primaverensis sp. nov. differs from $M$. cancer sp. nov. in the general shape of the male palpal bulb, with prolateral inferior keel distally thinner and rounded, as well as in possessing prolateral accessory keels, and retrolateral apophysis slendering towards apex. Females differ in possessing a wider and longer spermatheca. M. primaverensis sp. nov. differs from M. aldana comb. nov. in possessing a slightly developed accessory apophysis; in a higher number of prolateral accessory keels, wider prolateral inferior keel and an inconspicuous male palpal tibia retrolateral process. Females differ in the endites posteriorly wider and rounded. Both sexes differ in a slightly orange carapace, with black cephalic area. M. primaverensis sp. nov. differs from M. moderata sp. nov. in having retrolateral nodule of megaspines, a male bulb with secondary projection shorter and thinner, with more prolateral accessory keels, and an inconspicuous male palpal tibia retrolateral process. Females differ in having a carapace as long as wide.

Magnacarina primaverensis sp. nov. has the following character combination: male palpal bulb with a prominent primary projection strongly curved retrolaterally; retroaleteral keel thin and well developed; prolateral superior keel well developed, posterior extension ends almost on the back face of palpal bulb (Fig. 9A-C); secondary projection with prolateral accessory keels, increasing in size from proximal to distal (Fig. 9C-D). Prolateral inferior keel wide, increasing from back to front and distal end slightly oriented to apical (Fig. 9A, C-D). Apical keel well developed, wider in the middle (Fig. 9D-E). Accessory apophysis barely developed, bearing large megaspines apically (Fig. 8E). Retrolateral nodule of megaspines with large spines, stout at base and slendering apically (Fig. 8I). Spermatheca reduced, low, with one single receptacle variable in shape, and strongly sclerotized. Uterus externus that is wider, and four to five times longer than the spermatheca (Fig. 11A-D).

\section{Etymology}

The specific epithet is a combination of the noun referring to the area that the species inhabits, "Bosque de la Primavera", and the Latin suffix -ensis, which means "of or from a place". 

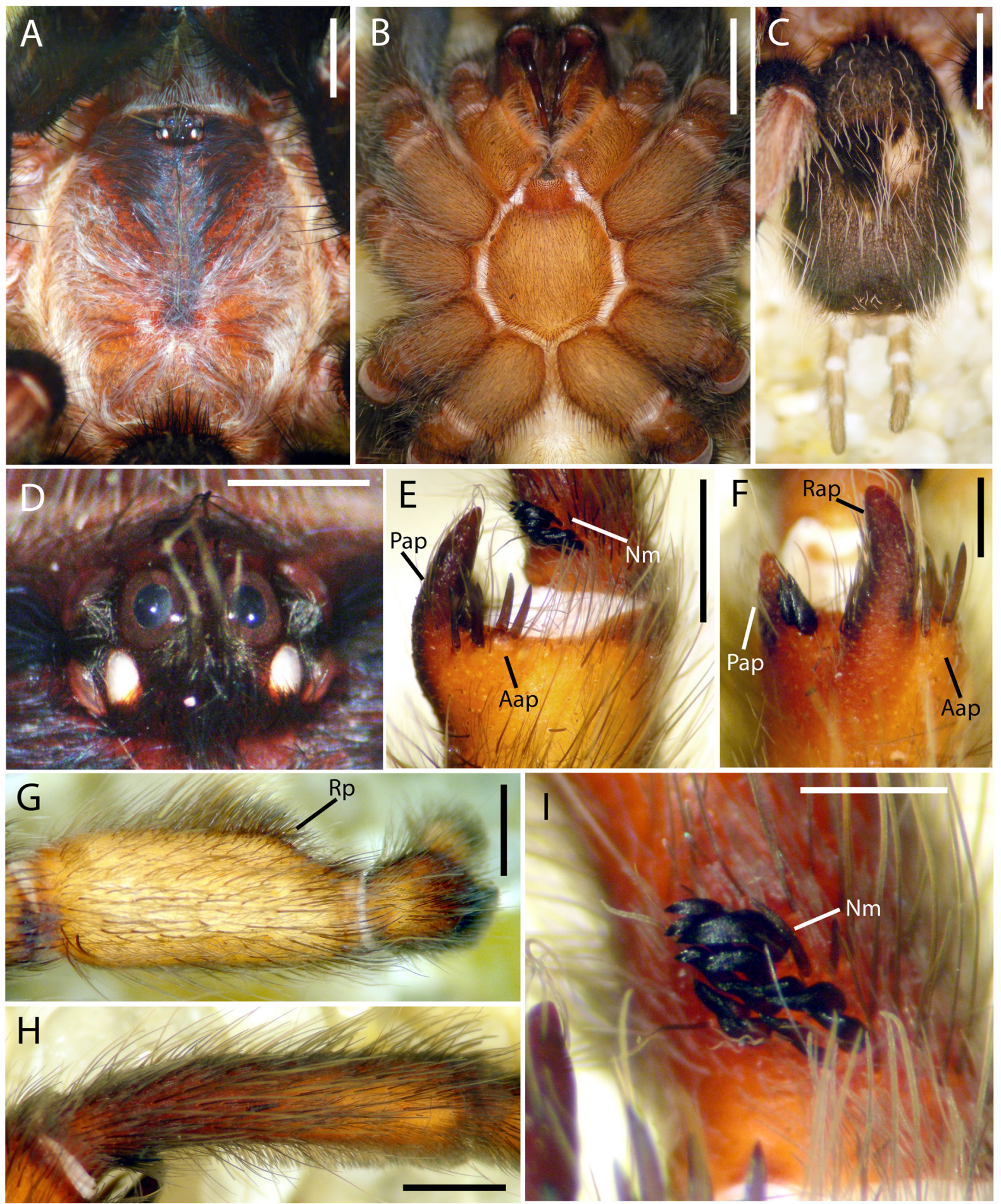

Fig. 8. Magnacarina primaverensis Mendoza \& Locht sp. nov., $\hat{\jmath}$, holotype (CNAN-T0995). A. Carapace, dorsal view. B. Prosoma, ventral view. C. Opisthosoma, dorsal view. D. Ocular tubercle, dorsal view. E-I. Left side. E. Tibial apophyses, retrolateral view. F. Tibial apophyses, ventral view. G. Palpal tibia, dorsal view. H. Metatarsus I, prolateral view. I. Retrolateral nodule with megaspines, retrolateral view. Scale bars: $A-C=2 \mathrm{~mm}$;, $\mathrm{G}-\mathrm{H}=1 \mathrm{~mm}$; D, F, I $=0.5 \mathrm{~mm}$. 


\section{Type material}

\section{Holotype}

MEXICO: §̃, Jalisco, Zapopan, Bosque de la Primavera, 10 Oct. 2012, coll. R. Orozco (CNAN-T0995).

\section{Paratypes}

MEXICO: 4 우, 1 $\widehat{\text { }}$, Jalisco, Zapopan, Bosque de la Primavera, 20 Aug. 2010, coll. J. Mendoza (females: CNAN-T0996, CNAN-T0999, CNAN-T1000 and CNAN-T1001; male: CNAN-T0998); 1 ठ, Jalisco, Zapopan, Carr. A Colotlán, casi llegando a Huaxtla, Oct. 2013, coll. G. Vila. (CNAN-T0997); 1 ô, Jalisco, Zapopan, Bosque de la Primavera, 21 Sep. 2013, coll. J. Mendoza (NHM).
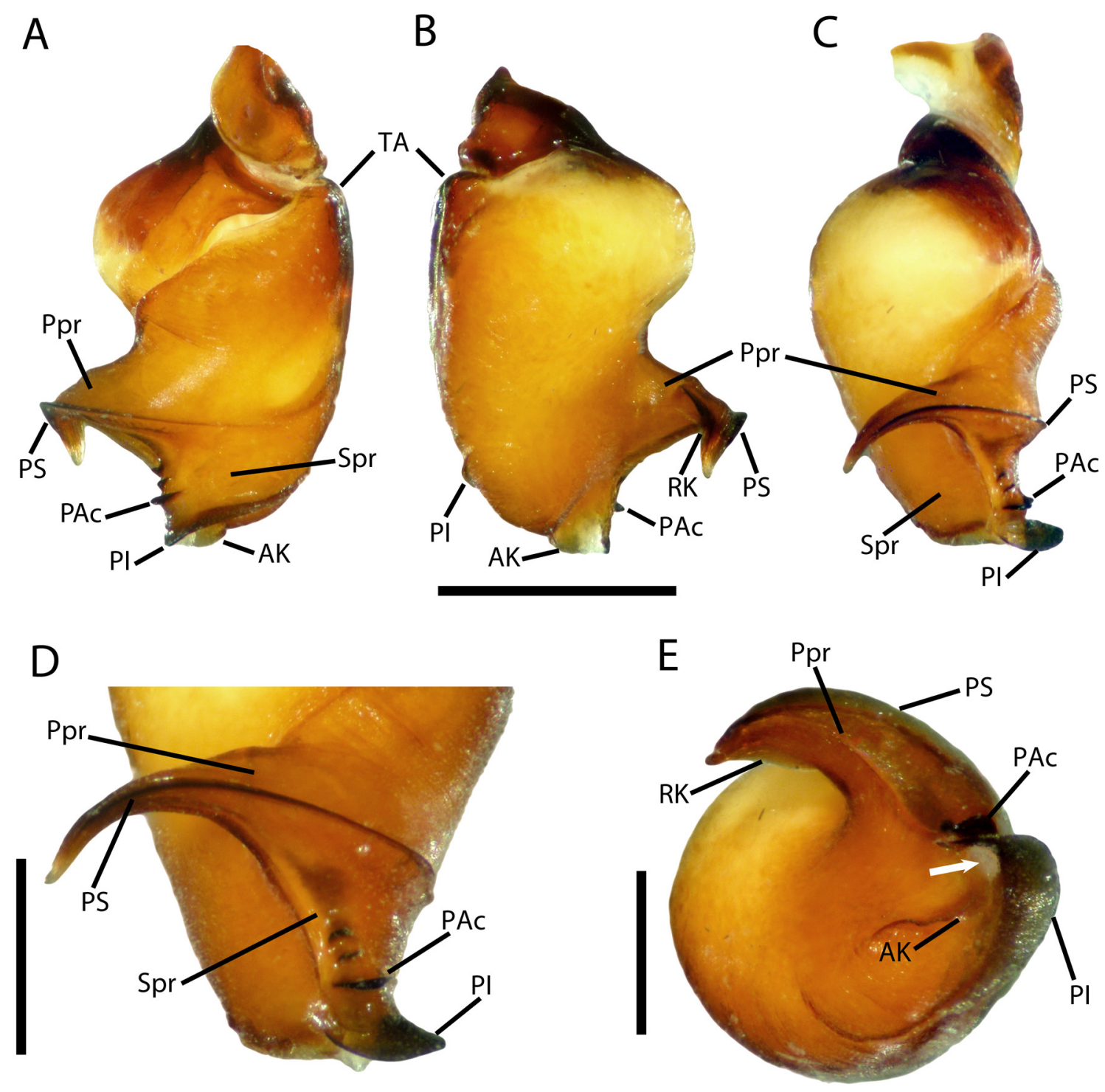

Fig. 9. Magnacarina primaverensis Mendoza \& Locht sp. nov., $\widehat{\jmath}$, holotype (CNAN-T0995), right palpal bulb. A. Prolateral view. B. Retrolateral view. C. Dorsal view. D. Apex, dorsal view. E. Apex, apical view. White arrow indicates sperm pore. Scale bars: $A-C=1 \mathrm{~mm}$; D-E $=0.5 \mathrm{~mm}$. 


\section{Description}

Holotype male CNAN-T0995 (Figs 8-9, 12A)

Body length (not including chelicerae and spinnerets) 16.39, carapace: 7.48 long, 6.44 wide. Caput not markedly elevated; fovea straight, 1.00 wide. Carapace with orange sheen setae and dark cephalic area (Fig. 8A). Eyes: anterior eye row procurved, posterior eye row, recurved. Eyes sizes and interocular distances: AME 0.325; ALE 0.275; PME 0.20; PLE 0.25; AME-AME 0.15; AME-ALE 0.05; PMEPME 0.50; PME-PLE 0.025; ALE-PLE 0.075. Ocular tubercle, width 1.05; length 0.875; clypeus 0.075 (Fig. 8D). Labium: length 0.5 ; width 1.30; with 72 cuspules. Maxilla inner corner with approximately 136-133 (left-right). Cheliceral promargin with 8-8 (left-right) teeth. Sternum length 3.35. Sigilla circular, only third pair hardly visible; posterior sigilla one and half times its length from the margin (Fig. 8B). Leg formula: IV > I > III > II. Length of legs and palpal segments (femur, patella, tibia, metatarsus, tarsus, total): I: $6.69,3.46,4.58,4.71,3.61,23.05$; II: $5.48,3.25,3.66,4.37,3.34,20.1$; III: 4.87, 3.09, 3.67, 4.97, 3.55, 20.15; IV: 6.40, 3.13, 5.47, 7.34, 4.28, 26.62. Palp: 4.25, 2.97, 3.75, -, 2.05, 13.02. Spinnerets: PMS, 1.03 long, 0.43 apart; PLS, 1.60 basal, 1.00 middle, 1.27 distal. Tarsi I-IV scopulate, II and III divided by narrow band of setae, IV divided by strong band of setae. Metatarsi I densely scopulate; II scopulate on distal two thirds, III scopulate on distal half and IV scopulate on distal third. Tibia I with three apophyses. Prolateral apophysis with one short and stout inner spine shorter than its length (Fig. 8F).

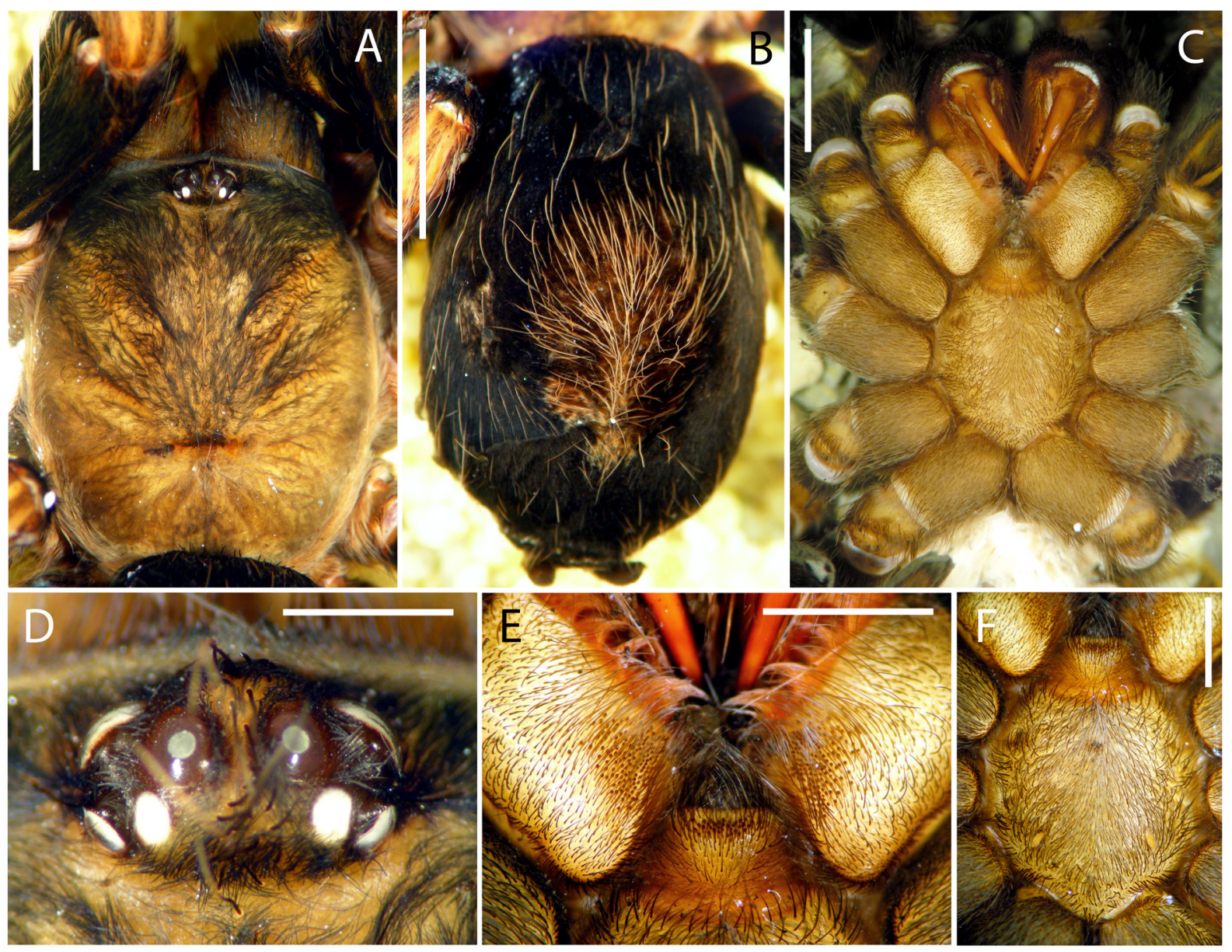

Fig. 10. Magnacarina primaverensis Mendoza \& Locht sp. nov., , paratype (CNAN-T0996). A. Carapace, dorsal view. B. Opisthosoma, dorsal view. C. Prosoma, ventral view. D. Ocular tubercle, dorsal view. E. Labial and maxillary cuspules, ventral view. F. Sternum, ventral view. Scale bars: A-C $=4 \mathrm{~mm}$; $\mathrm{E}-\mathrm{F}=2 \mathrm{~mm} ; \mathrm{D}=1 \mathrm{~mm}$. 
Retrolateral apophysis normally developed, slender and slightly curved to dorsal (Fig. 8E). Accessory apophysis barely developed, bearing five large megaspines at its apex (Fig. 8E). Metatarsus I curved (Fig. 8H), with retrolateral megaspines nodule with 14 large spines, stout at base and tapering apically (Fig. 8I). Retrolateral face of palpal tibiae with a short process, poorly developed on distal third (Fig. 8G). Chaetotaxy (left side): femora I 1p; II 1p; III 1p, 1r; IV 1r; palp 1p; patellae none; tibiae I 1p, 4v; II 2p, 5v; III 2p, 5v, 2r; IV 5v, 2r; palp none; metatarsi: I 1v; II 1p, 7v; III 4p, 7v, 2r; IV 3p, 7v, 2r. Palpal bulb with a prominent primary projection strongly curved retrolaterally with distal half twisted to apical. Retrolateral keel thin and well developed. Prolateral superior keel well developed, posterior extension ends almost on the back face of palpal bulb (Fig. 9A-B, E). Secondary projection short and wide, with three to six prolateral accessory keels well developed increasing in size from proximal to distal (Fig. 9C-D). Prolateral inferior keel wide, increasing from back to front, distal end slightly oriented to apical (Fig. 9A, C-D). Apical keel well developed, wider in the middle, covering the sperm pore which opens towards prolateral face (Fig. 9E). Tegular apophysis slightly developed (Fig. 9A-B). Urticating setae of type III arranged in one dorsomedian patch, with copper metallic iridescence (Fig. 8C, 12A). Variations summarized in Table 2.

Color pattern: In live specimens, carapace slightly orange with black cephalic area; ventral coxae, labium, maxillae and sternum dark brown; abdomen dorsally black with reddish setae and dorsomedian patch of copper-colored urticating setae, ventrally black. Legs and palps: femur with dark blue iridescence, patellae orange, tibiae, metatarsi and tarsi black (Fig. 12A).
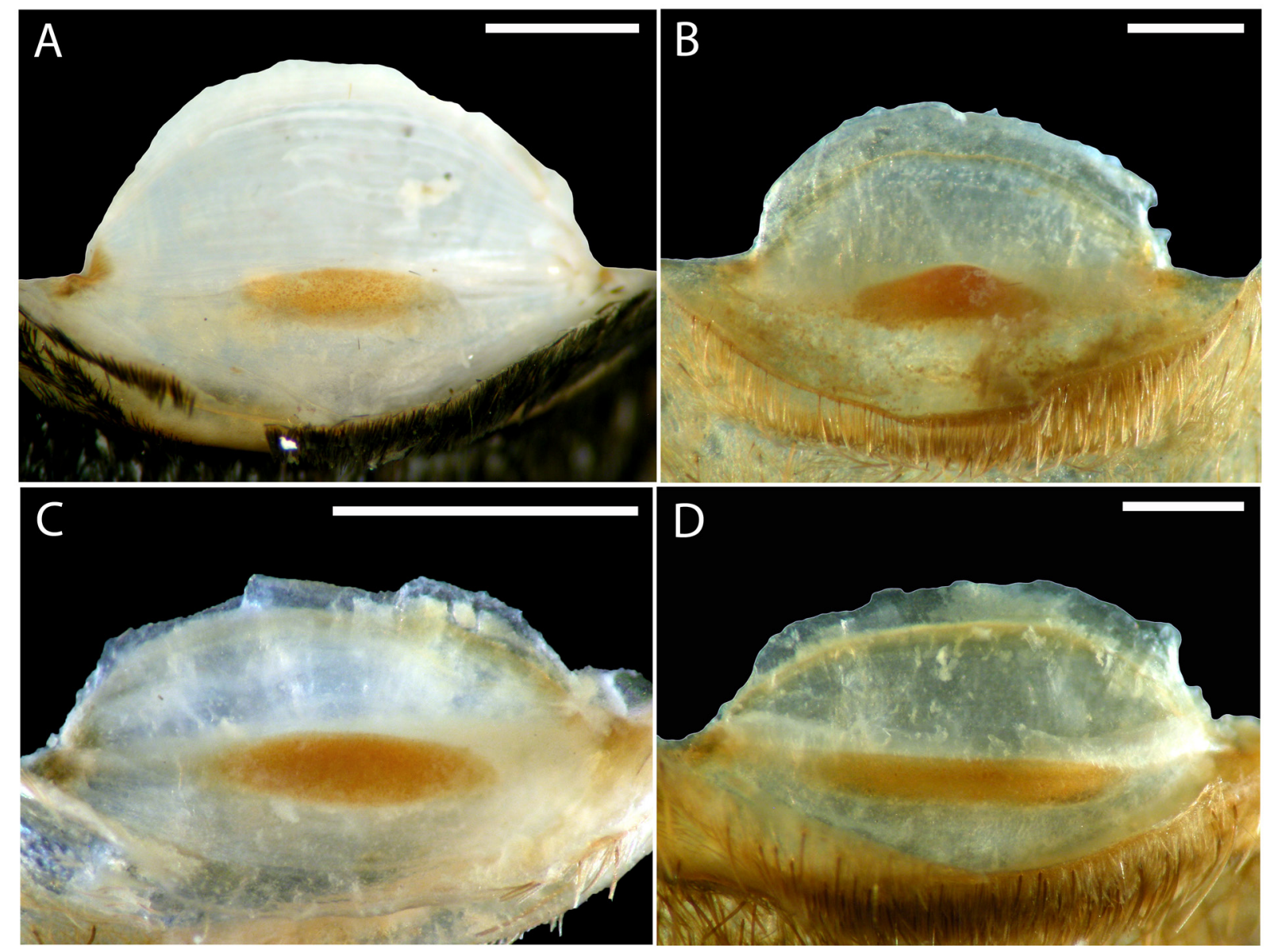

Fig. 11. Magnacarina primaverensis Mendoza \& Locht sp. nov., spermatheca, ventral view. A. + , paratype (CNAN-T0996). B. + , paratype (CNAN-T0999). C. +, paratype (CNAN-T1001). D. + $^{2}$ paratype $($ CNAN-T1000). Scale bars $=1 \mathrm{~mm}$. 
Table 2. Magnacarina primaverensis Mendoza \& Locht sp. nov. and Magnacarina moderata Locht, Mendoza \& Medina sp. nov. Variations of some quantitative characters in the specimens of the type series. Measurements in mm. Hyphens represents the interval between the lowest and highest value of each character. When left and right side values were taken, it was indicated as (left/right).

\begin{tabular}{l|cc|cc}
\hline \multicolumn{1}{c|}{ Specimens measurements } & \multicolumn{2}{c|}{ Magnacarina primaverensis sp. nov. } & \multicolumn{2}{c}{ Magnacarina moderata sp. nov. } \\
\hline \multirow{3}{*}{ Total length } & Males (3) & Females (4) & Male (1) & Females (2) \\
\cline { 2 - 5 } Carapace length & $13.79-16.39$ & $18.92-26.67$ & 15.19 & $14.5-18.18$ \\
Carapace width & $6.64-7.84$ & $7.78-11.82$ & 7.31 & $6.82-6.85$ \\
Sternum length & $6.32-6.47$ & $5.99-10.16$ & 5.42 & $5.21-5.60$ \\
Sternum width & $2.93-3.6$ & $3.37-5.20$ & 3.07 & $2.70-3.10$ \\
Labium length & $2.7-2.9$ & $3.27-5.0$ & & $2.80-3.0$ \\
Labium width & $0.5-0.93$ & $1.60-2.15$ & 0.90 & 0.93 \\
Chelicaral teeth (left/right) & $1.10-1.33$ & $0.93-1.30$ & 1.175 & $1.30-1.50$ \\
Labial cuspules & $7-8 / 8-10$ & $8-10 / 7-10$ & 9 & $8-9 / 9$ \\
Maxillary cuspules (left/right) & $48-72$ & $35-56$ & 58 & $62-75$ \\
Spermatheca length medially & $106-136 / 85-133$ & $93-206 / 104-200$ & $115 / 119$ & $134-164 / 123-163$ \\
Spermatheca base width & - & $0.20-0.34$ & - & $0.16-0.20$ \\
Accessorial apophysis spines (left side) & - & $0.86-1.40$ & - & $0.60-0.66$ \\
Number of megaspines in nodule (left side) & $12-14$ & - & 4 & - \\
\hline
\end{tabular}

Paratype female CNAN-T0996 (Figs 10, 11A, 12B)

Body length (not including chelicerae and spinnerets) 26.67, carapace: 11.82 long, 10.16 wide. Caput not markedly elevated; fovea straight, 2.10 wide. Carapace with orange sheen setae and dark cephalic area (Fig. 10A). Eyes: anterior eye row procurved, posterior eye row recurved. Eyes sizes and interocular distances: AME: 0.325; ALE: 0.525; PME: 0.325; PLE: 0.325; AME-AME: 0.30; AME-ALE: 0.15; PME-PME: 0.825; PME-PLE: 0.075; ALE-PLE: 0.225. Ocular tubercle, width 1.85; length 1.30; clypeus 0.2 (Fig. 10D). Labium: length 1.3 ; width 2.15 ; with 35 cuspules. Maxilla inner corner with approximately 162-152 (leftright) (Fig. 10E). Cheliceral promargin with 10-10 (left-right) teeth. Sternum length 5.20. Sigilla oval, first to third pairs hardly visible; posterior sigilla one and half times its length from the margin (Fig. 10C, F). Leg formula: IV > I > II > III. Length of legs and palpal segments (femur, patella, tibia, metatarsus, tarsus, total): I: 8.03, 5.13, 5.62, 4.60, 3.46, 26.84; II: 6.98, 4.50, 4.83, 4.59, 3.16, 24.06; III: 6.38, 3.81, 4.48, 5.42, 3.58, 23.67; IV: 8.26, 4.26, 5.66, 7.83, 4.63, 30.64. Palp: 6.17, 3.67, 3.90, -, 3.51, 17.25. Spinnerets: PMS, 1.07 long, 0.33 apart; PLS, 2.27 basal, 1.40 middle, 2.3 distal. Tarsi I-IV scopulate, II and III divided by narrow band of setae, IV divided by strong band of setae. Metatarsi I densely scopulate; II scopulate on distal two thirds, III scopulate on distal half, and IV scopulate on distal third. Chaetotaxy (left side): femora II 1p; III 1p, 1r; palp 1p; patellae none; tibiae II 1p, 2v; III 2p, 4v, 2r; IV 4v, 2r; palp 5v; metatarsi I 1v; II 5v; III 4p, 6v, 2r; IV 3p, 8v, 2r.

Spermatheca reduced, low with one single semicircular receptacle, strongly sclerotized. Uterus externus is twice wider, and five times longer than the spermatheca (Fig. 11A). Variation: spermatheca medially longer. Also can be lower but twice wider than normally seen (Fig. 11B-D). Urticating setae of type III, arranged in one dorsomedian patch, with copper metallic iridescence (Fig. 10B, 12B). Variations summarized in Table 2.

Color pattern: In live specimens, carapace slightly orange with black cephalic area; ventral coxae, labium, maxillae and sternum dark brown; abdomen dorsally black with reddish setae and dorsomedian patch of copper-colored urticating hairs, ventrally black. Legs and palps: femur with dark blue iridescence, patellae orange, tibiae, metatarsi and tarsi black (Fig. 12B). 


\section{Color pattern}

Color pattern of these spiders changes during their development. Spiderlings of M. primaverensis sp. nov. have a black carapace; the abdomen dorsum is dark with a central patch of urticating hairs. All the femora are black; patellae, tibia, metatarsi and tarsi are orange in color $\left(2^{\text {nd }}\right.$ to $6^{\text {th }}$ instar). In larger stadia, the carapace is dark brown with larger black cephalic area; the rest of the body remains as spiderling color $\left(7^{\text {th }}\right.$ to $8^{\text {th }}$ instar). As the individuals grow, the carapace becomes orange with black cephalic area; the abdomen dorsum develops a few red setae; palps and legs show dark blue iridescent color on femora, patellae becomes orange in color; and tibiae, metatarsi and tarsi become black ( $9^{\text {th }}$ instar onwards). This last coloration is stronger in adults, especially in males. Recently molted specimens have more vivid colors as observed in other theraphosids. In pre-molting individuals, colors are more opaque.

\section{Distribution and natural history}

Known only from the Natural Protected Area "Bosque de la Primavera", near Jalisco, México (Fig. 16). All the spiders were found during daytime in a primary forest protected area. They live under rocks in shallow scrapes. The spiders are more difficult to find during the dry season. One of the females was found with a group of 25 spiderlings, with a legspan of $2.5 \mathrm{~cm}$, suggesting that the spiderlings remain with the mother for a few months (Fig. 12C-D). Since there were no systematic collecting efforts to estimate the size of the population, the density of the distribution cannot be ascertained. The area is under increasing pressure from human activities of the nearby city of Guadalajara, and it is possible that the only existing population is in the protected area of "Bosque de la Primavera".
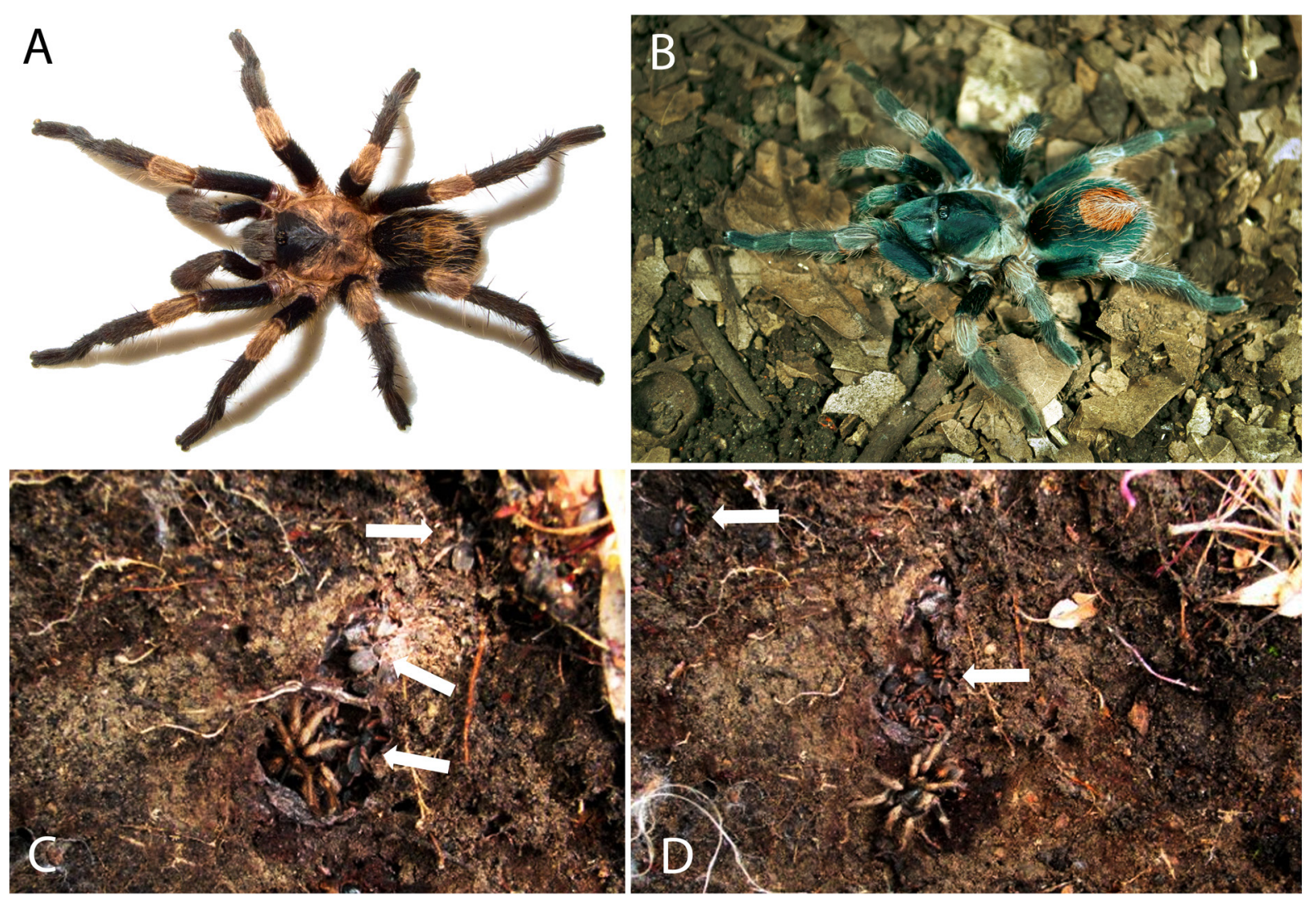

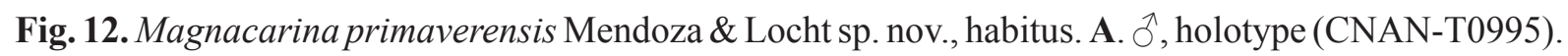
B. + , paratype (CNAN-T0996). C-D. Habitat burrow, white arrows indicates location of spiderlings. Photos: J. Mendoza (A, B); G. Vila (C, D). 


\section{Magnacarina moderata Locht, Mendoza \& Medina sp. nov. urn:lsid:zoobank.org:act:74AF9502-86F8-4A92-B782-1A50555D8BD4}

Figs 13-16

\section{Diagnosis}

Magnacarina moderata sp. nov. differs from all other Magnacarina species in lacking retrolateral nodule of megaspines and having only one prolateral accessory keel well developed. Magnacarina moderata sp. nov. also differs in possessing a secondary projection that is thinner and larger that of the other species, with a short and apically directed prolateral inferior keel. Females differ in carapace distinctly larger than wide.

Magnacarina moderata sp. nov. possesses the following character combination: male palpal bulb with a prominent primary projection strongly curved retrolaterally, with distal half slightly apically directed (Fig. A-C); retrolateral keel thin and slightly developed. Prolateral superior keel wide along its entire length, posterior extension ends almost in the middle of prolateral face (Fig. 14D-E); secondary projection is elongated and directed to apical, with one prolateral accessory keel well developed (Fig. 14C-D). Prolateral inferior keel wide, divided in two sections, increasing from back to front and distal end oriented to apical (Fig. 14A-B, D). Apical keel well developed, wider distally. Sperm pore is located between prolateral inferior and apical keels (Fig. 14D-E). Accessory apophysis slightly developed, bearing large megaspines at the apex (Fig. 13G-H). Metatarsus I lacking retrolateral nodule of megaspines (Fig. 13H). Spermatheca reduced, low, with one single receptacle oval in shape, strongly sclerotized. Uterus externus is three times wider, and four to five times longer than the spermatheca (Fig. 15E-F).

\section{Etymology}

The specific epithet is the latinized version of "moderate", moderatus fem. moderata, referring to the shape of the secondary projection in the male palpal bulb which is moderately elongated and thinner than in other species.

\section{Type material}

Holotype

MEXICO: §ิ, Nayarit, Acaponeta, 14 Nov. 1939, coll. C.M. Bogert and H.E. Vokes (CNAN-T1003).

\section{Paratypes}

MEXICO: 2 q 9 , Sinaloa, 70 mi South of Mazatlan, 24 Jul. 1954, coll. W.J. Gertsch (CNAN-T1004 and AMNH).

\section{Description}

Holotype male CNAN-T1003 (Figs 13-14)

Body length (not including chelicerae and spinnerets) 15.19, carapace: 7.31 long, 5.42 wide. Caput not markedly elevated; fovea procurved, 1.33 wide. Carapace with orange sheen setae (Fig. 13A). Eyes: anterior eye row procurved, posterior eye row, recurved. Eyes sizes and interocular distances: AME 0.24; ALE 0.32; PME 0.18; PLE 0.22; AME-AME 0.12; AME-ALE 0.08; PME-PME 0.46; PME-PLE 0.02; ALE-PLE 0.16. Ocular tubercle, width 1.18; length 0.84; clypeus 0.12 (Fig. 13D). Labium: length 0.90 ; width 1.175; with 58 cuspules. Maxilla inner corner with approximately 115-119 (left-right). Cheliceral promargin with 9-9 (left-right) teeth. Sternum length 3.07. Sigilla circular, second and third pairs hardly visible; posterior sigilla half its length from the margin (Fig. 13B). Leg formula: IV > I > III > II. Length of legs and palpal segments (femur, patella, tibia, metatarsus, tarsus, total): I: 5.29, 3.29, 3.41, 4.25, 2.26, 18.50; II: 4.71, 3.08, 3.33, 3.30, 2.64, 17.06; III: 4.18, 2.66, 3.03, 3.44, 2.55, 15.86; IV: $5.78,3.13,4.43,4.95,3.10,21.39$. Palp: 3.96, 2.82, 3.26, -, 1.29, 11.33. Spinnerets: PMS, 0.53 long, 


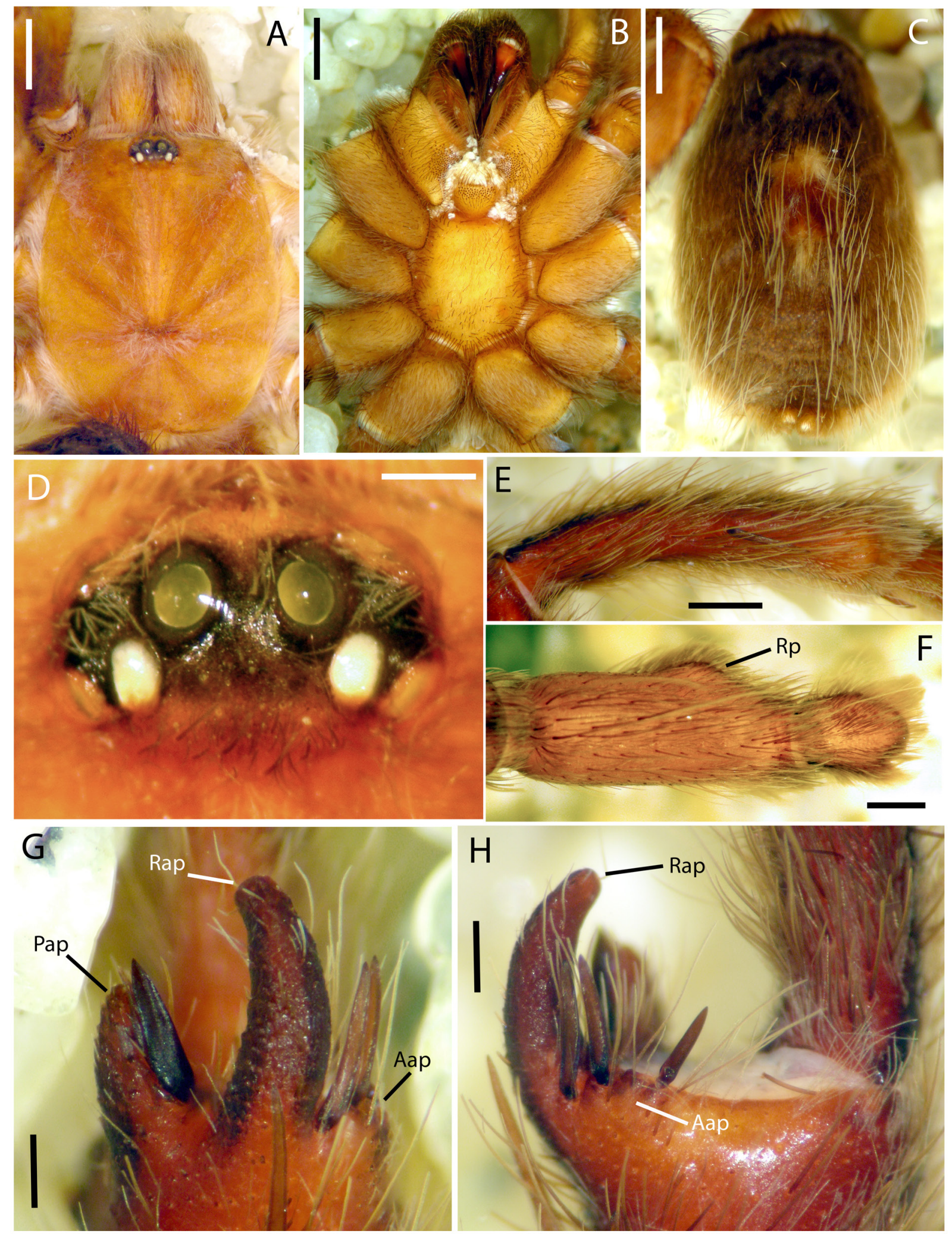

Fig. 13. Magnacarina moderata Locht, Mendoza \& Medina sp. nov., §, holotype (CNAN-T1003). A. Carapace, dorsal view. B. Prosoma, ventral view. C. Opisthosoma, dorsal view. D. Ocular tubercle, dorsal view. Left side: E. Metatarsus I. Prolateral view. F. Palpal tibia, dorsal view. G. Tibial apophyses, ventral view. H. Tibial apophyses, retrolateral view. Scale bars: $A-C=2 \mathrm{~mm} ; \mathrm{E}-\mathrm{F}=1 \mathrm{~mm} ; \mathrm{D}, \mathrm{G}-\mathrm{H}=0.5 \mathrm{~mm}$. 
0.20 apart; PLS, 0.97 basal, 0.63 middle, 1.10 distal. Tarsi I-IV scopulate, I and II divided by narrow band of setae, III and IV divided by strong band of setae. Metatarsi I scopulate on distal two thirds; II scopulate on distal half, III scopulate on distal half, and IV scopulate on distal fourth.

Tibia I with three apophyses, prolateral apophysis with one inner larger spine (Fig. 13G). Retrolateral apophysis slightly curved to dorsal (Fig. 13G, H). Accessory apophysis slightly developed, bearing four large megaspines at its apex (Fig. 13H). Metatarsus I curved (Fig. 13E), lacking retrolateral megaspines nodule (Fig. 13H). Retrolateral face of palpal tibiae with a short process, slightly developed on distal half (Fig. 13F). Chaetotaxy (left side): femora I 1p; II 1p; III 1r; IV 2r; palp none; patellae none; tibiae I
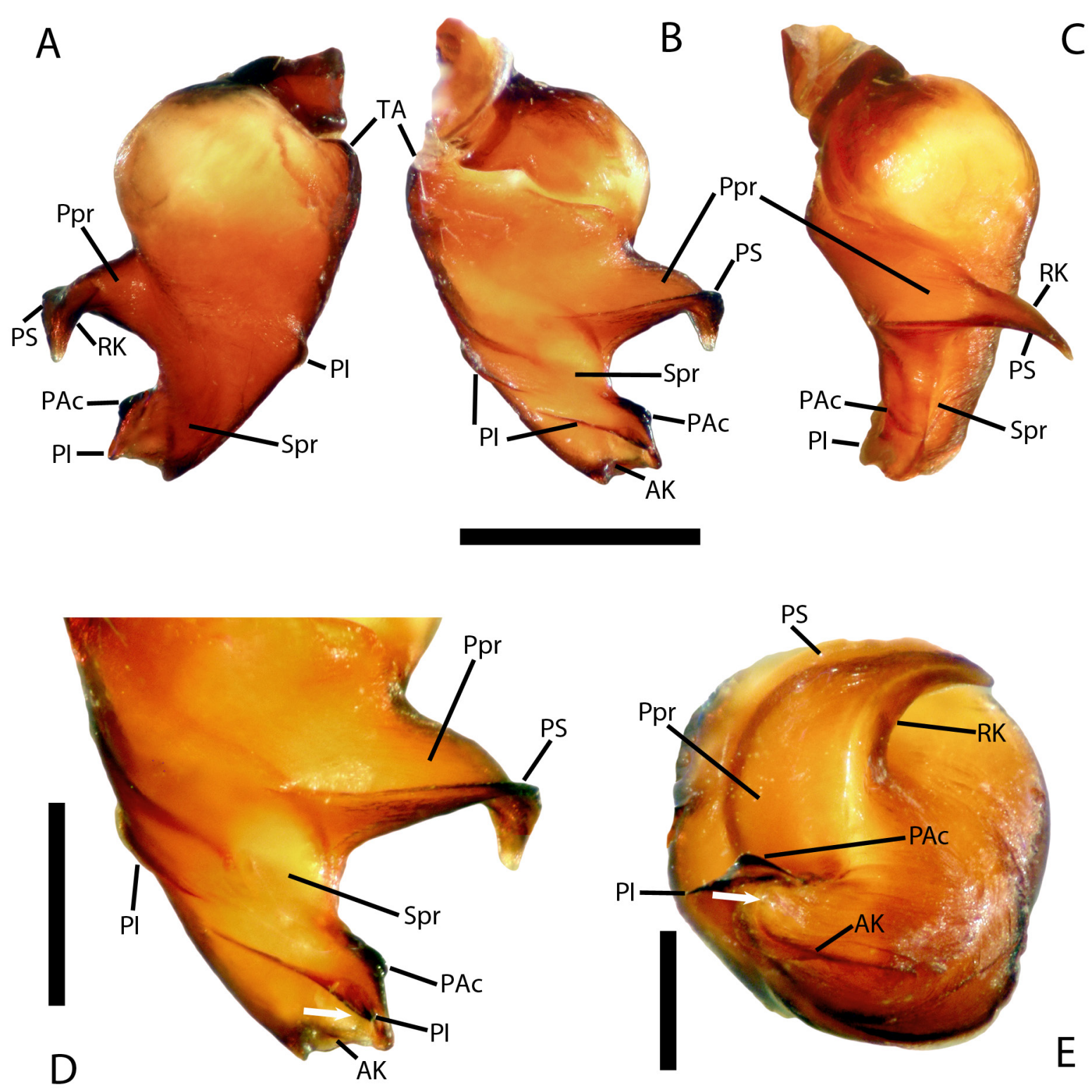

Fig. 14. Magnacarina moderata Locht, Mendoza \& Medina sp. nov., §̋, holotype (CNAN-T1003), left palpal bulb. A. Prolateral view. B. Retrolateral view. C. Dorsal view. D. Apex, dorsal view. E. Apex, apical view. White arrow indicates sperm pore. Scale bars: A-C $=1 \mathrm{~mm}$; D-E $=0.5 \mathrm{~mm}$. 
3p, 4v; II 3p, 8v; III 2p, 7v, 3r; IV 9v, 4r; palp none; metatarsi: I 1p, 2v; II 3p, 8v; III 3p, 8v, 2r; IV $2 \mathrm{p}, 8 \mathrm{v}, 2 \mathrm{r}$. Palpal bulb with a prominent primary projection strongly curved retrolaterally, with distal half slightly twisted to apical (Fig. A-C). Retrolateral keel thin and slightly developed. Prolateral superior keel wide along its entire length, posterior extension ends almost in the middle of prolateral face (Fig. 14D-E). Secondary projection elongated with one prolateral accessory keel well developed (Fig. 14B, D). Prolateral inferior keel wide, divided in two sections, increasing from back to front, distal end oriented to apical (Fig. 14A-B, D). Apical keel well developed, wider distally. Sperm pore is located between prolateral inferior and apical keels, and opens towards prolateral face (Fig. 14D-E). Tegular apophysis slightly developed (Fig. 14A-B). Urticating setae of type III arranged in one dorsomedian patch, with copper metallic iridescence (Fig. 13C). Variations summarized in Table 2.

Color pattern: damaged by preservation in ethanol, carapace tegument looks yellowish; ventral coxae, labium, maxillae and sternum brown; abdomen dorsally brown with yellowish setae, ventrally brown. Urticating setae with copper metallic iridescence. Legs and palps: brownish.

Paratype female CNAN-T1004 (Fig. 15A-E)

Body length (not including chelicerae and spinnerets) 14.50, carapace: 6.85 long, 5.60 wide. Caput not markedly elevated; fovea procurved, 1.17 wide. Carapace with orange sheen setae (Fig. 15A). Eyes: anterior eye row procurved, posterior eye row, recurved. Eyes sizes and interocular distances: AME 0.225;
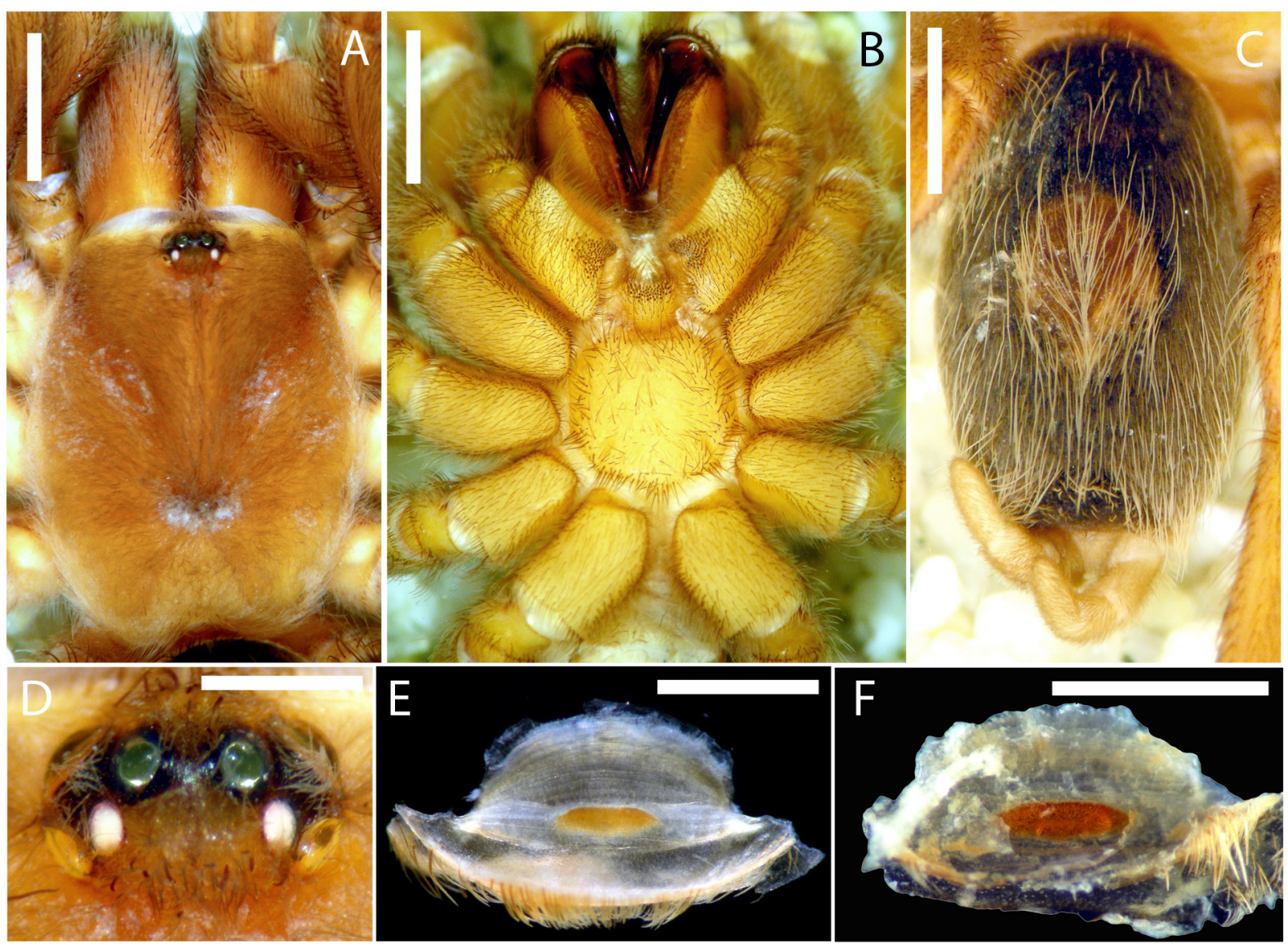

Fig. 15. Magnacarina moderata Locht, Mendoza \& Medina sp. nov. A-E. , paratype (CNAN-T1004). A. Carapace, dorsal view. B. Prosoma, ventral view. C. Opisthosoma, dorsal view. D. Ocular tubercle, dorsal view. E. Spermatheca, ventral view. F. o, paratype $(A M N H)$, spermatheca, ventral view. Scale bars: A-C $=2 \mathrm{~mm}$; E-F $=1 \mathrm{~mm}$; D $=0.5 \mathrm{~mm}$. 
ALE 0.35; PME: 0.125; PLE: 0.275; AME-AME: 0.175; AME-ALE: 0.075; PME-PME: 0.55; PMEPLE: 0.025; ALE-PLE: 0.10. Ocular tubercle, width 1.225; length 0.95; clypeus lacking (Fig. 15D). Labium: length 0.93 ; width 1.50; with 62 cuspules. Maxilla inner corner with approximately 134-123 (left-right). Cheliceral promargin with 9-9 (left-right) teeth. Sternum circular, length 3.10. Sigilla oval, second and third pair hardly visible; posterior sigilla once its length from the margin (Fig. 15B). Leg formula: IV > I > II > III. Length of legs and palpal segments (femur, patella, tibia, metatarsus, tarsus, total): I: 4.75, 3.17, 3.44, 2.53, 2.28, 16.17; II: 4.11, 2.93, 2.55, 2.39, 2.36, 14.34; III: 3.46, 2.43, 2.45, 2.90, 2.24, 13.48; IV: 4.99, 2.82, 3.85, 4.16, 3.05, 18.87. Palp: 3.43, 2.43, 2.29, -, 2.79, 10.94. Spinnerets: PMS, 0.87 long, 0.43 apart; PLS, 1.63 basal, 0.90 middle, 1.03 distal. Tarsi I-IV densely scopulate, I and II divided by narrow band of setae, III and IV divided by strong band of setae. Metatarsi I densely scopulate; II scopulate on distal two thirds, III scopulate on distal half, and IV scopulate on distal fourth. Chaetotaxy (left side): femora I 1p; II 1p; III 1p, 1r; IV 1r; palp 1p; patellae none; tibiae II 1v; III 2p, 4v, 2r; IV 5v, 2r; palp 3v; metatarsi I 2v; II 4v; III 3p, 7v, 2r; IV 3p, 9v, 2r. Spermatheca fused, low with one single receptacle oval in shape, strongly sclerotized. Uterus externus is three times wider, and four to five times longer than the spermatheca (Fig. 15E-F). Urticating setae of type III, arranged in one dorsomedian patch, with copper metallic iridescence (Fig. 15C). Variations summarized in Table 2.

Color pattern: damaged by preservation in ethanol, carapace tegument looks yellowish; ventral coxae, labium, maxillae and sternum brown; abdomen dorsally brown with yellowish setae, ventrally brown. Urticating setae with copper metallic iridescence. Legs and palps: brownish.

\section{Distribution}

Known only from the border area between the states of Nayarit and Sinaloa (Fig. 16), this species inhabits scrapes under rocks in deciduous forest.

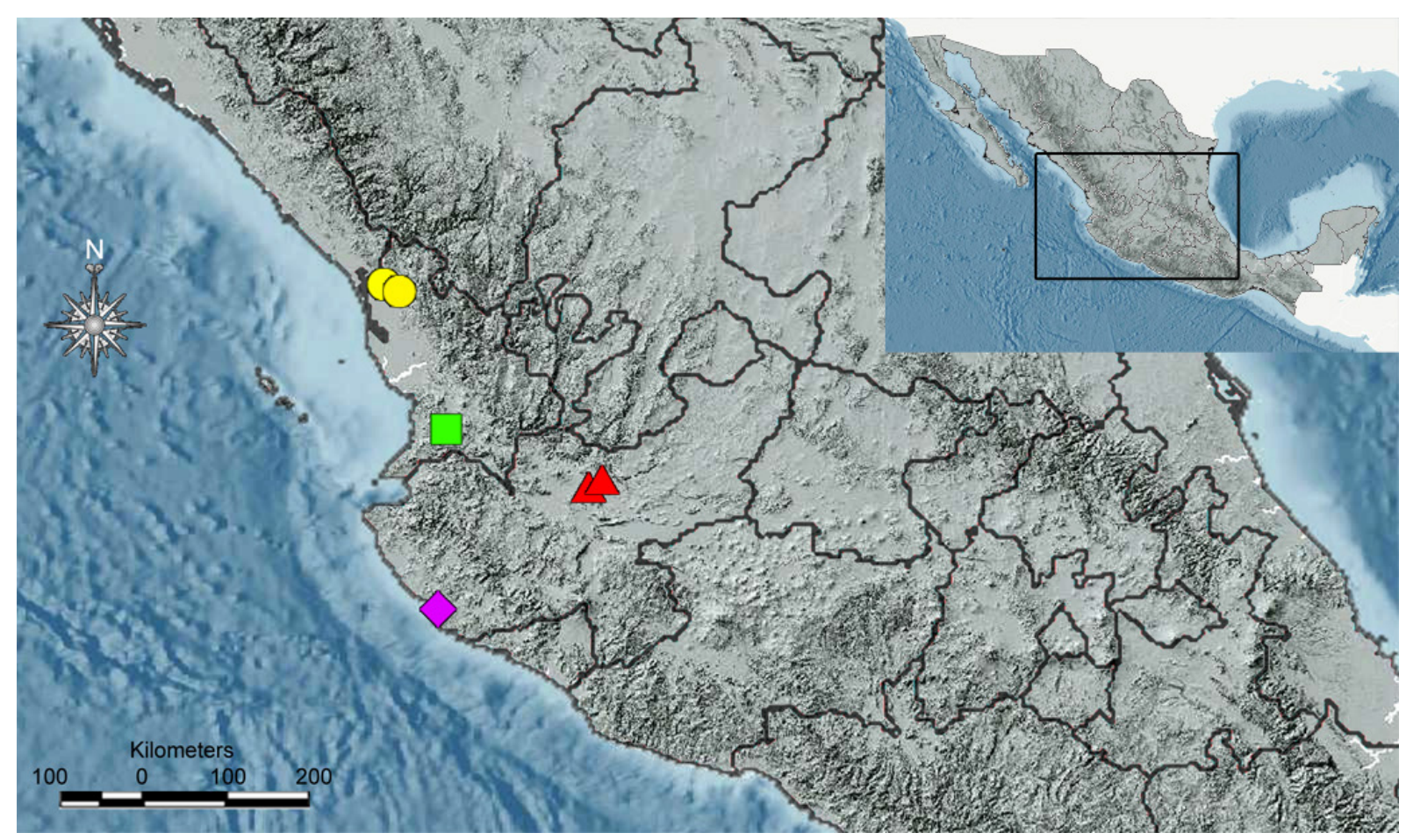

Fig. 16. Distribution map identifying known records of Magnacarina gen. nov. species in Mexico: Jalisco, Nayarit and Sinaloa states. $\square=$ M. aldana (West, 2000); $\boldsymbol{\Delta}=$ M. primaverensis Mendoza \& Locht sp. nov.; $\diamond=$ M. cancer Mendoza \& Locht sp. nov.; $\bullet$ M. moderata Locht, Mendoza \& Medina sp. nov. 


\section{Discussion}

West (2000) described Hapalopus aldanus and placed it in the genus, based on the shape of the male palpal bulb, the presence of a basoventral tubercle on metatarsus I, and the shape of the monolobed spermatheca. Unfortunately, he based his comparison with the male type of Hapalopus formosus (Ausserer, 1875) only on the illustrations by Gerschman \& Schiapelli (1973) and suggested a continued study of male Hapalopus congeners. We have reviewed the material of all other known Mexican theraphosids with the type III urticating setae (i.e., Bonnetina, Cardiopelma, Davus and Schizopelma), and also the South American genera Cyriocosmus and Hapalopus for better comparison of morphological features. One of the most important challenges of this study was determining the homology of male palpal bulb keels and projections. The bulb of Magnacarina gen. nov. is characterized by two unique projections: a primary projection with PS and RK keels, and a secondary projection with PI and AK keels. As the PS and PI keel generally occur on the embolus only (Bertani 2000), it is considered that this new taxon has a bifid embolus.

Although the position of the keels and their designation in bulbs of Bonnetina, Schizopelma, Davus and Cardiopelma seem to be clear and straightforward, in order to fit Magnacarina gen. nov. into this taxonomic scheme we must accept that the Ppr is an embolar projection formed by the fusion of PS and RK keels. Consequently, the Spr is extremely short, and a wide embolus carrying PI keel, AK keel and PAc keels in some cases. The male palpal bulb morphology in Bonnetina, Schizopelma, Davus and Cardiopelma is relatively congruent with this interpretation; additionally, the PI keel bears teeth (Bonnetina) or a developed subapical tooth (Schizopelma, Davus, Cardiopelma). A "ring-shaped" structure of PI and AK keels was observed in Cardiopelma, with the sperm pore between PI and AK keels, similar to that of Hapalopus; this corresponds with the position of the sperm pore in Magnacarina species, located between PI and A keels. Based on the morphological evidence, we consider our proposed homologies for keels is correct. Additionally, the naming of the new structures Ppr and Spr is necessary as nothing similar to these structures has been previously described.

\section{Acknowledgments}

JM thanks the Consejo Nacional de Ciencia y Tecnología (CONACYT), for the financial support to conduct research at the American Museum of Natural History (AMNH), New York, United States. Oscar F. Francke and Griselda Montiel are thanked for providing access to the type material deposited in the Colección Nacional de Arácnidos (CNAN), Instituto de Biología, UNAM. We thank Dr. Norman I. Platnick for providing access to the type and additional material deposited in the AMNH, and for his hospitality during JM's research stay. We thank Ignacio Vazquez for providing access to the material deposited in the Laboratorio de Acarología Anita Hoffmann (LAAH). We also thank Enrique Ramirez Garcia from the arachnid collection in Estación Biológica Chamela, UNAM, for providing access to their material. Louis Sorkin and Fernando Medina Alcala are thanked for their help and hospitality when JM was in New York City. JM thanks the members of the laboratory of arachnology (CNAN) for their support and help on field trips, as well as David Ortiz for enriching discussions on the morphology of Bonnetina. Images of live specimens and habitat were kindly supplied by Rick C. West and Guillermo Vila. We thank Chris Hamilton for the language revision and valuable comments. We also thank the editors and three anonymous reviewers for their critical reading and valuable comments. The specimens were collected under the scientific collection permit FAUT-0175 from SEMARNAT to Oscar F. Francke.

\section{References}

Bertani R. 2000. Male palpal bulbs and homologous features in Theraphosinae (Araneae, Theraphosidae). Journal of Arachnology 28 (1): 29-42.

Bertani R. 2001. Revision, cladistic analysis, and zoogeography of Vitalius, Nhandu, and Proshapalopus; with notes on other theraphosine genera (Araneae, Theraphosidae). Arquivos de Zoologia 36 (3): 265-356. 
Estrada-Alvarez J.C. 2014. New data from mygalomorph spiders (Araneae: Mygalomorphae) of Estado de Mexico, with taxonomic comments about the genus Davus O. Pickard-Cambridge, 1892. Dugesiana 21: 55-66.

Gerschman B.S. \& Schiapelli R.D. 1973. La subfamilia Ischnocolinae (Araneae, Theraphosidae). Revista del museo Argentino de ciencias naturales 'Bernardino Rivadavia' 4: 42-77.

Goloboff P.A. 1995. A revision of the South American spiders of the family Nemesiidae (Araneae, Mygalomorphae). Part I. Species from Peru, Chile, Argentina, and Uruguay. Bulletin of the American Museum of Natural History 224, American Museum of Natural History, New York.

Locht A., Medina F., Rojo R. \& Vázquez I. 2005. Una nueva especie de tarántula del género Aphonopelma Pocock 1901 (Araneae, Theraphosidae, Theraphosinae) de México con notas sobre el género Brachypelma Simon 1891. Boletín de la Sociedad Entomologica Aragonesa 37: 105-108.

Locht A. 2008. Estudio sobre la sistemática y distribución de la familia Theraphosidae (Arachnida, Araneae) en México. Master thesis, Facultad de Ciencias, Universidad Nacional Autónoma de México, México City.

Locht A. \& Medina F. 2008. Una nueva especie de tarántula del género Bonnetina Vol, 2000 (Araneae, Theraphosidae, Theraphosinae), de México. Boletín de la Sociedad Entomológica Aragonesa 43: 45-48.

Mendoza J.I. 2012a. Bonnetina papalutlensis a new species of tarantula from Guerrero, Mexico, with notes on reproduction (Araneae, Theraphosidae, Theraphosinae). Revista Ibérica de Aracnología 20: $57-62$.

Mendoza J.I. 2012b. Cotztetlana omiltemi, a new genus and species of tarantula from Guerrero, México (Araneae, Theraphosidae, Theraphosinae). Arthropoda Scientia 2: 2-7.

Mendoza J.I. 2014a. Taxonomic revision of Hemirrhagus Simon, 1903 (Araneae: Theraphosidae, Theraphosinae), with description of five new species from Mexico. Zoological Journal of the Linnean Society 170 (4): 634-689. http://dx.doi.org/10.1111/zoj.12112

Mendoza J.I. 2014b. Psalmopoeus victori, the first arboreal theraphosid spider described for Mexico (Araneae: Theraphosidae: Aviculariinae). Revista Mexicana de Biodiversidad 85 (3): 728-735. http:// dx.doi.org/10.7550/rmb.44597

Ortíz D. \& Francke O. 2014. Two new species of Bonnetina tarantulas (Theraphosidae: Theraphosinae) from Mexico: contributions to morphological nomenclature and molecular characterization of types. Journal of Natural History 49 (11-12): 685-707. http://dx.doi.org/10.1080/00222933.2014.924770

Pérez-Miles F. 1994. Tarsal scopula division in Theraphosinae (Araneae, Theraphosidae): Its systematic significance. Journal of Arachnology 22: 46-53.

Schmidt G. 2003. Die Vogelspinnen: Eine weltweite Übersicht. Neue Brehm-Bücherei 641, WestarpWissenschaften, Hohenwarsleben.

Schmidt G. 2012. Bonnetina (Pachytheca) tanzeri subgen. et sp. n., eine bisher unbeschriebene Vogelspinnenart aus Mexiko (Araneae: Theraphosidae: Theraphosinae). Arthropoda Scientia 2: 21-28.

Vol F. 1999. À propos d'une spermathèque inhabituelle. Arachnides 42: 1-13.

Vol F. 2000. Description de Bonnetina cyaneifemur, gen. n. \& sp. n. (Araneae, Theraphosidae, Theraphosinae) du Mexique. Arachnides 44: 2-9.

Vol F. 2001. Description d'une deuxième espèce de Bonnetina Vol, 2000 du Mexique, B. rudloffi sp. n. (Araneae, Theraphosidae, Theraphosinae) et comparaison avec B. cyaneifemur. Arachnides. 48: 7-16. 
West R.C. 2000. Some new theraphosids from western Mexico (Araneae, Mygalomorphae). The Southwestern Naturalist 45 (3): 299-305. http://dx.doi.org/10.2307/3672832

World Spider Catalog. 2016. Natural History Museum Bern. Available online at http://wsc.nmbe.ch, version 17.0 [accessed 20 Feb. 2016].

Manuscript received: 26 October 2015

Manuscript accepted: 12 April 2016

Published on: 23 September 2016

Topic editor: Rudy Jocqué

Desk editor: Charlotte Thionois

Printed versions of all papers are also deposited in the libraries of the institutes that are members of the EJT consortium: Muséum national d'Histoire naturelle, Paris, France; Botanic Garden Meise, Belgium; Royal Museum for Central Africa, Tervuren, Belgium; Natural History Museum, London, United Kingdom; Royal Belgian Institute of Natural Sciences, Brussels, Belgium; Natural History Museum of Denmark, Copenhagen, Denmark; Naturalis Biodiversity Center, Leiden, the Netherlands. 